\title{
Heavy Metals Removal from Electroplating Wastewater by Waste Fiber-Based Poly(amidoxime) Ligand
}

\author{
Md. Lutfor Rahman ${ }^{1,2, *(\mathbb{D}, \text { Zhi Jian Wong }}{ }^{1}$, Mohd Sani Sarjadi ${ }^{1}{ }^{\circledR}$, Sabrina Soloi ${ }^{1}$, Sazmal E. Arshad ${ }^{1}{ }^{\circledR}$, \\ Kawi Bidin ${ }^{3}$ and Baba Musta ${ }^{1}$ \\ 1 Industrial Chemistry Program, Faculty of Science and Natural Resources, Universiti Sabah Malaysia, \\ Kota Kinabalu 88400, Sabah, Malaysia; javentwong@gmail.com (Z.J.W.); msani@ums.edu.my (M.S.S.); \\ sabrinas@ums.edu.my (S.S.); sazmal@ums.edu.my (S.E.A.); babamus@ums.edu.my (B.M.) \\ 2 Seaweed Research Unit, Faculty of Science and Natural Resources, Universiti Malaysia Sabah, \\ Kota Kinabalu 88400, Sabah, Malaysia \\ 3 Environmental Science Program, Faculty of Science and Natural Resources, Universiti Malaysia Sabah, \\ Kota Kinabalu 88400, Sabah, Malaysia; kbidin@ums.edu.my \\ * Correspondence: lotfor@ums.edu.my
}

Citation: Rahman, M..L.; Wong, Z.J.; Sarjadi, M.S.; Soloi, S.; Arshad, S.E.; Bidin, K.; Musta, B. Heavy Metals Removal from Electroplating Wastewater by Waste Fiber-Based Poly(amidoxime) Ligand. Water 2021, 13, 1260. https://doi.org/ 10.3390/w13091260

Academic Editor: Laura Bulgariu

Received: 25 March 2021

Accepted: 24 April 2021

Published: 30 April 2021

Publisher's Note: MDPI stays neutral with regard to jurisdictional claims in published maps and institutional affiliations.

Copyright: (c) 2021 by the authors. Licensee MDPI, Basel, Switzerland. This article is an open access article distributed under the terms and conditions of the Creative Commons Attribution (CC BY) license (https:/ / creativecommons.org/licenses/by/ $4.0 /)$.

\begin{abstract}
An efficient and economical treatment technology for heavy metal removal from the electroplating wastewaters is needed for the water purification. Therefore, pure cellulosic materials were derived from two waste fiber (pandanus fruit and durian rind) and conversion of the cellulose into the poly(acrylonitrile)-grafted material was accomplished by free radical grafting system. Thereafter, poly(amidoxime) ligand was produced from the grafted materials. Sorption capacity $\left(\mathrm{q}_{\mathrm{e}}\right)$ of several toxic metals ions was found to be high, e.g., copper capacity $\left(q_{\mathrm{e}}\right)$ was $298.4 \mathrm{mg} \mathrm{g}^{-1}$ at $\mathrm{pH}$ 6. In fact, other metal ions, such as cobalt chromium and nickel also demonstrated significant sorption capacity at $\mathrm{pH}$ 6. Sorption mechanism played acceptable meet with pseudo second-order rate of kinetic pattern due to the satisfactory correlation with the experimental sorption values. A significant correlation coefficient $\left(\mathrm{R}^{2}>0.99\right)$ with Langmuir model isotherm showed the single or monolayer sorption occurred on the surfaces. The reusability study showed that the polymer ligand can be useful up to six cycles with minimum loss (7\%) of efficiency and can be used in the extraction of toxic metal ions present in the wastewaters. Therefore, two types of electroplating wastewater were used in this study, one containing high concentration of copper (23 ppm) and iron (32 ppm) with trace level of others heavy metals (IWS 1) and another containing high concentration of copper (85.7 ppm) only with trace level of others heavy metals (IWS 2). This polymeric ligand showed acceptable removal magnitude, up to $98 \%$ of toxic metal ions can be removed from electroplating wastewater.
\end{abstract}

Keywords: adsorption; waste fiber; poly(amidoxime); wastewater; heavy metals

\section{Introduction}

Water pollution has been drastically increased over the decades and heavy metal contamination has contributed a concerning amount to the pollution, thereby raising an urgency to find the best remediation method to remove heavy metals [1]. On the other hand, in the current era of globalization, the earth is confronted by the abundant obstructive substances generated by humans, animals and man-made activities [2]. As a result, our planet faces a number of environmental problems, such as water pollution, unsustainable solid waste generation, climate change or global warming, resulting in significant environmental deterioration over the long-term $[3,4]$. The effect of these environmental issues on economic and social development is atrocious.

The electroplating process have been performed for the implementation of metal plating to a surface of a finished product to protect against corrosion [5]. The principal useful elements for plating are zinc, brass, copper, nickel, iron, silver, gold, lead and chromium plating [6,7]. The electroplating technique comprises several activities like acid 
pickling, alkaline cleaning, plating, and rinsing resulting huge amount of heavy metals, cyanides, nitrates and sulphate complexes in the wastewater [7-9]. The concentration of some metal ions is high in the electroplating wastewater [10-13]. Exposure of high level of heavy metals may cause diverse health effect such as disruption of the endocrine system, respiratory organs, and kidney and liver damage, as well as lung cancer [14]. Certainly, wastewater produced by the electroplating industries is extremely colored, turbid, low $\mathrm{pH}$, inducing bio-distortion through discharge into plants via the soil resulting in food toxins and an unbalanced ecosystem [15].

Electroplating industries have generated a large quantity of wastewater containing mostly various toxic heavy metals [16-20]. According to the technology employed at electroplating process, wastewater can be classified into acidic and alkaline wastewater [21]. Acidic wastewater can be turned into sludges by precipitation using $\mathrm{pH}$ adjustment and coagulation $[17,18]$. On the other hand, alkaline wastewater contains complex agents such as citric acid, EDTA or tartaric acid, which prompt a metal-organic complex formation whereby heavy metals cannot be hydrolyzed, even after adjusting higher $\mathrm{pH}$ values $(>12)[22,23]$. Heavy metals are unfavorable to precipitate in alkaline wastewater through $\mathrm{pH}$ adjustment, therefore, treatment processes required longer time with $\mathrm{pH}$ adjustment, cationic exchange, extraction or precipitation with special agents [23-28]. A wide variety of heavy metals is present into the electroplating effluents with various concentrations as $\mathrm{g} / \mathrm{L}$ to trace level, thus, heavy metals must be removed effectively until the discharge standard for wastewater is met $[25,29]$.

Generally, two methods have been utilized for toxic metals elimination from alkaline electroplating wastewater [30-37]. One of them is the dissociation of organic complex by the process of Fenton or wet oxidation [31-33]. Thus, Shin et al. [31] reported that $95 \%$ citrate was removed from the citrate-Ni complex by Fenton oxidation with $20 \mathrm{mM}$ $\mathrm{Fe}(\mathrm{II})$ and $1.08 \mathrm{M}$ hydrogen peroxide after the adjusted to $\mathrm{pH} 3$, and further wastewater was adjusted $\mathrm{pH} 10$ to created Ni precipitation and removal up to $99.9 \%$. Another report suggested that gluconic acid complex can be decomposed by micro-electrolysis system which take place precipitation of $\mathrm{Cu}$ and removal more than $90 \%$ [33]. Another removal method has been utilized by addition of specific chemical compounds and/or chemically modified resins [34-37]. Thus, about $99.6 \%$ of Cu-complex using EDTA was catch by sodium diethyldithiocarbamate and precipitation occurred by the coagulation with polyferric sulfate and polyacrylamide [34]. The least number of aminopolycarboxylic acids and diethylenetriaminepentaacetic acid forming chelate heavy metals [35]. Therefore, such organic compounds created a chelate complex with heavy metals on the surface of chemically modified resins to improve the removal of metals from electroplating wastewater [36,37].

Both methods required expensive agents to elimination of metals ions from alkaline wastewater. On the other hand, a simple operating method can be used for adsorption process. Numerous adsorbents comprise a different functional group to sorption of metal ions. However, it shows low affinity of surface functional groups to metals ions contrast to complex agents [38]. Consequently, a new adsorbent is needed to be generated for treatment of alkaline electroplating wastewater. The elimination of pollutants by conventional treatment methods is tough work [39], thus, an innovative technique is desired to solve this the problem.

The standard treatment strategies have been employed for reducing/elimination of heavy metals from wastewater. For example, adsorption [40], precipitation [41], coagulation [42], reverse osmosis [43], and membrane filtration [44] have been conventionally used in industry processes. The adsorption by bio-adsorbents also been validated as a promising and cost-effective method among other methods to get safe water [45]. In general, the basic characteristics of a good adsorbent should exhibit broad adsorption capacity, rapid rate of adsorption, easy to separate or recover from the water [46,47]. Overall, numerous types of materials have been applied as adsorbent for many applications such as water treatment, catalysis, desiccants, indicators etc. There are a lot of adsorbent for the removal of contami- 
nants or pollutants but some of the commonly used adsorbents are activated carbon [48], cellulose [49], natural minerals [50], silica [51,52], biopolymers [53] and nanomaterials [54].

Chemically modified cellulose can be a potential bio-adsorbents, consequently, chemical conversion of the cellulose might intensify its sorption performance as an efficient adsorbent [55]. The free radical polymerization method is widely used to produce the grafting copolymers from various cellulose materials. A variety of methods mainly either chemical or radiation have been utilized to produce free radicals for polymerization reactions. However, ceric ions generated from ceric ammonium nitrate (CAN) can be a simple method to produce initiator radicals for grafting copolymerisation. Certainly, the radicals are created on the cellulose (AGU, anhydroglucose unit), resulting in covalent bonds formed with the desired monomers, and many propagating units are growing until termination process occurs. Ultimately, a grafting copolymer product can be generated via disproportionation step or in a combination of two growing cellulose molecules [56-58]. Eventually, chemical conversion of the grafted cellulose into the chelating ligands for the coordination with metals ions involve a simple binding system. In principle, atoms, molecules or small groups of atoms that exhibit a negative or neutral charge, which may connect to a central metal atom, eventually form a coordination compound $[59,60]$.

In this study, pure cellulose was chemically extracted from two waste fiber. Then, the cellulose was converted into poly(acrylonitrile)-grafted materials by the radical copolymerization procedure. Further, the grafted cellulose was converted into the poly(amidoxime) ligand for sorption of toxic metals from wastewater. Characterization was performed by spectroscopy analysis and detailed adsorption was carried out, such as the effect of $\mathrm{pH}$ on the adsorption capacity, kinetic study and Langmuir and Freundlich adsorption isotherm studies.

\section{Materials and Methods}

\subsection{Chemicals and Instruments}

Waste pandanus fruit fiber were obtained from Melinsung summer bay in Papar, Sabah, Malaysia. On the other hand, durian rinds were obtained from a random fruit market in Kota Kinabalu, Sabah. Sodium hydroxide (Systerm, Kuala Lumpur, Malaysia), glacial acetic acid (J.T. Baker, Phillipsburg, NJ, USA), hydrogen peroxide (QRec, Kuala Lumpur, Malaysia), ceric ammonium nitrate (Sigma-Aldrich, St. Louis, MO, USA), acrylonitrile (Sigma-Aldrich, St. Louis, MO, USA), ethanol (Merck, Darmstadt, Germany), sulphuric acid (Systerm, Kuala Lumpur, Malaysia), hydroxylamine hydrochloride (SigmaAldrich, St. Louis, MO, USA), sodium acetate (Systerm, Kuala Lumpur, Malaysia), acetone, (Systerm, Kuala Lumpur, Malaysia), hydrochloric acid (Merck, Darmstadt, Germany), copper(II) nitrate (Sigma-Aldrich, St. Louis, MO, USA), nickel(II) nitrate (Sigma-Aldrich, St. Louis, MO, USA), lead(II) nitrate (Sigma-Aldrich, St. Louis, MO, USA), cobalt(III) nitrate (Sigma-Aldrich, Missouri, MO, USA), iron(III) nitrate (Sigma-Aldrich, St. Louis, MO, USA) were used reagent grade. Acrylonitrile monomer was passed through columns filled with chromatographic grade activated alumina to remove inhibitors. Metal salts and other analytical grade reagents were used without purification.

A Perkin-Elmer FT-IR Spectrometer (Spectrum 100) (Perkin Elmer, Waltham, MA, USA) was used to finding functional groups of intermediate and products. The samples were analyzed using $\mathrm{KBr}$ pellets. Approximately $20 \mathrm{mg}$ of sample was mixed with dry $\mathrm{KBr}$ pellet, smoothly crushed and analyzed with FT-IR instrument. Inductively Coupled Plasma Optical Emission Spectrometry (Perkin Elmer OPTIMA 7300 DV ICP-OES, Waltham, MA, USA) was used in this study for determining heavy metal ions concentrations in solution. A pH meter (Mettler-Toledo AG, Schwerzenbach, Switzerland) was used to prepare the sodium acetate buffer solution. Oven (Protech ABBI-50, Kuala Lumpur, Malaysia) and Shaker machine (Protech model 721, Kuala Lumpur, Malaysia) are used in this study. 


\subsection{Extraction of Cellulose}

Waste pandanus fruit fiber and durian rinds were cut and grounded it. About $100 \mathrm{~g}$ pandanus and $100 \mathrm{~g}$ durian rinds waste fiber were boiled with $800 \mathrm{~mL} 18 \%$ of sodium hydroxide solution $(\mathrm{NaOH})$ for $5 \mathrm{~h}$. The fibers were then cleaned by tap water and then cooked with approximately $600 \mathrm{~mL}$ of glacial acetic acid for an hour followed by washing with distilled water. After that, $400 \mathrm{~mL}$ of hydrogen peroxide as a bleaching agent was added into the cooking fibers and followed by $400 \mathrm{~mL}$ of $8 \% \mathrm{NaOH}$ and boiled it for $1 \mathrm{~h}$. The resulting cellulose was cleaned by tap water for 5 times and dry it at $50{ }^{\circ} \mathrm{C}$. The dried cellulose was used in grafting process [49].

\subsection{Graft Copolymerization}

A round bottom flask $(1.0 \mathrm{~L})$ was immersed into thermostat water bath and set-up with a magnetic stirrer bar and condenser for a copolymerization reaction. About $6.5 \mathrm{~g}$ of cellulose, $500 \mathrm{~mL}$ of distilled water, $1.1 \mathrm{~mL}^{\circ} \mathrm{H}_{2} \mathrm{SO}_{4}(50 \%), 1.1 \mathrm{~g}$ of ammonium ceric nitrate in $10 \mathrm{~mL}$ distilled water and $10 \mathrm{~mL}$ of acrylonitrile are heated at $55^{\circ} \mathrm{C}$ with stirring under $\mathrm{N}_{2}$ atmosphere, the reaction was carried out according to previous work [59]. The workup procedure was accomplished by previous work [59]. The poly(acrylonitrile)-grafted cellulose product was dry at $50^{\circ} \mathrm{C}$ for $20 \mathrm{~h}$.

\subsection{Synthesis of Poly(amidoxime) Ligand}

Before oximation reaction began, about $300 \mathrm{~mL}$ of hydroxylamine solution was make ready according to the previous work [49]. About $10.0 \mathrm{~g}$ of the grafted materials was added into a flask with freshly prepared hydroxylamine solution $(\mathrm{pH} \mathrm{10)}$ and the mixture was stirred at $70{ }^{\circ} \mathrm{C}$ for $6 \mathrm{~h}$ using water bath. The work-up procedure was accomplished by previous work [49]. The resulting poly(amidoxime) ligand dried at $50^{\circ} \mathrm{C}$ for $24 \mathrm{~h}$.

\subsection{Batch Adsorption Studies}

Various $\mathrm{pH}$ (3-6) solution were used for a series of batch adsorption expt. to ascertain the metal ion binding capacity according to previous work [57-59]. Typically, $100 \mathrm{mg}$ of poly(amidoxime), $5 \mathrm{~mL}$ of distilled water, $10 \mathrm{~mL}$ of $0.1 \mathrm{M}$ of $\mathrm{CH}_{3} \mathrm{COONa}$ buffer ( $\mathrm{pH} 3$ to 6) were placed into plastic bottles. Exactly $5 \mathrm{~mL}$ of $0.1 \mathrm{M}$ of metal ions solution (copper sulphate- $5 \mathrm{H}_{2} \mathrm{O}$, cobalt chloride, chromium chloride and nickel sulphate) were added into plastic bottles stirred for two hours. After the adsorption reached equilibrium, the metal cation concentration is analyzed by ICP-OES. The metal ions concentration can be estimated by the following Equation (1):

$$
\mathrm{q}_{\mathrm{e}}=\frac{\left(\mathrm{C}_{\mathrm{o}}-\mathrm{C}_{\mathrm{e}}\right) \mathrm{V}}{\mathrm{L}}
$$

where $\mathrm{q}_{\mathrm{e}}$ stand for adsorption capacity $\left(\mathrm{mg} \mathrm{g}^{-1}\right) . \mathrm{C}_{\mathrm{o}}$ and $\mathrm{C}_{\mathrm{e}}$ are the initial and equilibrium concentration of metal ions $\left(\mathrm{mg} \mathrm{L}^{-1}\right)$, respectively. $\mathrm{V}$ is the volume of the metal ions solution $(\mathrm{mL})$ and $\mathrm{L}$ is the mass of polymeric ligand $(\mathrm{g})$.

A similar batch adsorption experiment was performed for the isothermal study according to the previous work [61,62]. Therefore, $100 \mathrm{mg}$ of adsorbent, $10 \mathrm{~mL}$ of distilled water and $5 \mathrm{~mL}$ of $0.1 \mathrm{M}$ of $\mathrm{CH}_{3} \mathrm{COONa}$ buffer at $\mathrm{pH} 6$ were mixed in a plastic bottle. Then exactly $5 \mathrm{~mL}$ of metal ion solution was added separately (different concentration, $10 \mathrm{ppm}$ to $2400 \mathrm{ppm}$ ). Every mixture was stirred for $2 \mathrm{~h}$. After equilibrium adsorption, the metal action concentration is analyzed by ICP-OES according to Equation (1).

Several batch adsorption study were performed for the kinetic adsorption studies according to the previous work [63-65]. Therefore, the $100 \mathrm{mg}$ of adsorbent, $5 \mathrm{~mL}$ of distilled water, $10 \mathrm{~mL}$ of $0.1 \mathrm{M}$ of $\mathrm{CH}_{3} \mathrm{COONa}$ buffer solution at $\mathrm{pH}$ 6, exactly $5 \mathrm{~mL}$ of $0.1 \mathrm{M}$ of metal ion solution were taken a series of PVC bottles. The mixture was stirred by using shaker machine at time intervals of 5, 15, 30, 60 and $120 \mathrm{~min}$. Then, concentrations of 
metal cation were determined by ICP-OES and calculation was performed by using the following Equation (2):

$$
\mathrm{q}_{\mathrm{t}}=\frac{\left(\mathrm{C}_{\mathrm{o}}-\mathrm{C}_{\mathrm{t}}\right) \mathrm{V}}{\mathrm{L}}
$$

where $q_{t}$ is the quantity of metal ions adsorbed at time $t\left(\mathrm{mg} \mathrm{g}^{-1}\right)$. The other parameters are the same according to Equation (1).

\subsection{Desorption and Reusability Studies}

A real-life practical application of the polymeric adsorbent, adsorption-desorption and reusability studies is needed to verify the stability and cost-effective nature of the adsorbent. For a typical desorption, all metal ions are held at the adsorbent as a metal-complexes. The metal ions are removed from the ligand by using $2 \mathrm{M}$ of $\mathrm{HCl}$ solution. The ligand was regenerated back by washed with water until remaining $\mathrm{HCl}$ removed from the ligand. Then, $\mathrm{CH}_{3} \mathrm{COONa}$ buffer of $\mathrm{pH} 6$ was added with every cycle of adsorption experiment for the reusability test of five cycles of adsorption-desorption process [49].

\subsection{Electroplating Wastewater Treatment by Poly(Amidoxime) Ligand}

A conical flask containing electroplating wastewater samples (IWS 1 and IWS 2), which obtained from an electroplating industry (PCB etching), Porcel, Singapore. ICP-OES analysis showed that IWS 1 containing high concentration of copper ( $23 \mathrm{ppm}$ ) and iron (32 ppm) with trace level of others heavy metals and IWS 2 containing high concentration of copper (85.7 ppm) only with trace level of others heavy metals. Then, $0.30 \mathrm{~g}$ of poly(amidoxime) ligand was added to both the flask containing $50 \mathrm{~mL}$ each wastewater. The mixtures were stirred with magnetic bar for $2 \mathrm{~h}$. The metal concentrations were analyzed by ICP-OES (metal ions concentrations before treatment and after ligand treatment).

\section{Results and Discussion}

\subsection{Synthesis of Cellulose-Supported Chelating Ligand}

After cellulose was extracted from two waste fibers (pandanus fruit fiber and durian rinds), the acrylonitrile was employed to the preparation of poly(acrylonitrile)-grafted cellulosic materials in this study [49] and the cellulose-grafted copolymer was then chemically converted to chelating ligand. The poly(acrylonitrile)-grafted cellulose was further reacted with hydroxylamine to produce the poly(amidoxime) ligand, the reaction scheme is presented at supporting information (Scheme S1). As expected, poly(amidoxime) chelating ligand was showed yellow-brown color as referred to earlier report $[49,57]$. The chelating ligand was synthesized using the reported optimum conditions, whereby the mixture was constantly agitated under $\mathrm{pH} 10$ for $4 \mathrm{~h}$ [57]. In this study, $10.00 \mathrm{~g}$ of cellulose-grafted poly(acrylonitrile) yielded $12.6 \mathrm{~g}$ of poly(amidoxime) chelating ligand. The purpose of grinding was to increases the surface area of the adsorbent for higher adsorption capacity during adsorption process being performed. During adsorption process, poly(amidoxime) ligand binding with $\mathrm{Cu}^{2+}$ ions, creating poly(amidoxime)-Cu complex and other metalligand complexes were also created by cobalt, chromium and nickel ions. The images of poly(amidoxime)-metal complexes such as $\mathrm{Cu}^{2+}, \mathrm{Co}^{2+}, \mathrm{Cr}^{3+}$, and $\mathrm{Ni}^{2+}$ is presented at supporting information (Figure S1).

\subsection{FT-IR Study}

FT-IR spectra of cellulose is presented in Figure 1a. A wide peak is detected at $3371 \mathrm{~cm}^{-1}$ owing for the presence of O-H stretching and absorption of $2907 \mathrm{~cm}^{-1}$ representing the stretching of $\mathrm{C}-\mathrm{H}$ band in the cellulose structure. A short peak at $886 \mathrm{~cm}^{-1}$ can be noted that the existence of $\mathrm{C}_{1}-\mathrm{H}$ deformation of glycosidic linkage of the cellulosic backbone [66]. An extensive peak was spotted at $1152 \mathrm{~cm}^{-1}$, which is a typical vibration of C-O-C pyranose ring of the cellulose molecule. Another two short peaks shown at $1624 \mathrm{~cm}^{-1}$ and $1408 \mathrm{~cm}^{-1}$, representing the bending modes of absorbed $\mathrm{H}_{2} \mathrm{O}$, and $\mathrm{CH}_{2}$ bands, respectively. 


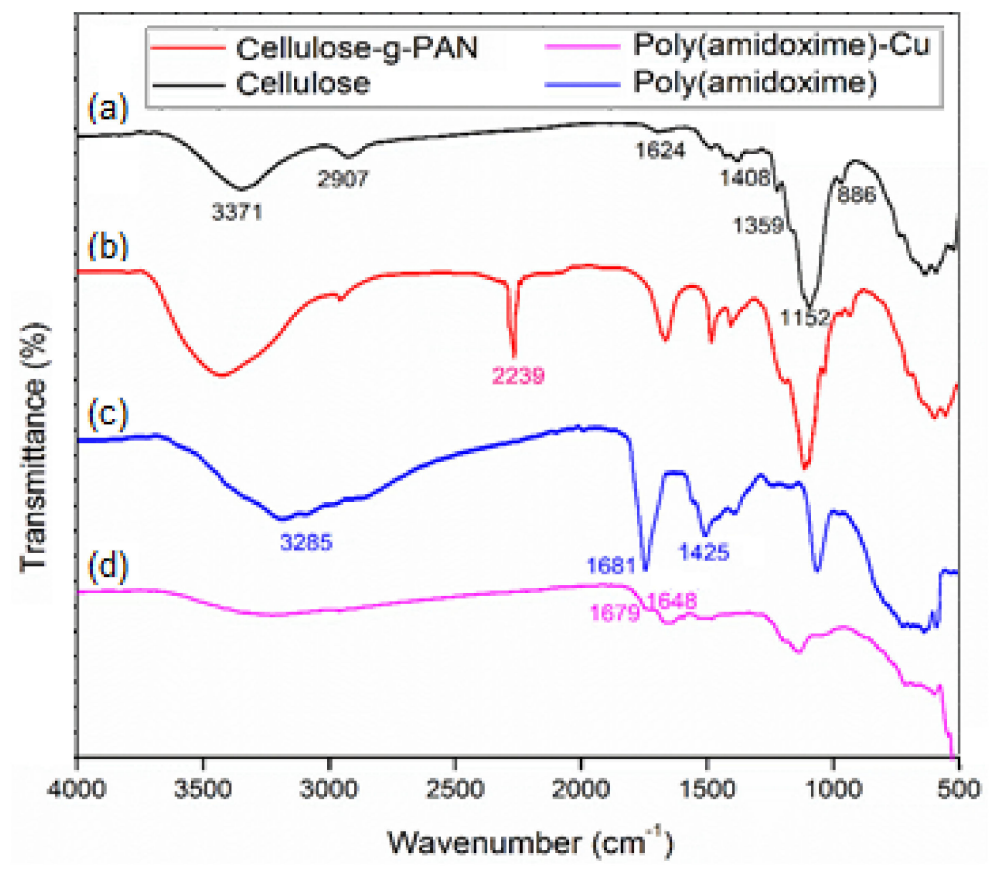

Figure 1. FT-IR spectra of (a) waste fiber cellulose, (b) cellulose-graft-poly(acrylonitrile) (cellulose-gPAN), (c) poly(amidoxime) and (d) amidoxime-copper by coordination system.

After modification of cellulose, the FT-IR spectra of the poly(acrylonitrile)-grafted cellulose is displayed by the red colored line in Figure $1 \mathrm{~b}$. A new important sharpened peak at $2239 \mathrm{~cm}^{-1}$ indicating the existence of $\mathrm{C} \equiv \mathrm{N}$ stretching of acrylonitrile functional groups. The CN starching at $2239 \mathrm{~cm}^{-1}$ is anticipated peak due to the monomer acrylonitrile was participating to the grafting process with the cellulose. Despite the expected peak for $\mathrm{CN}$ is established in the spectrum of cellulose-graft-poly(acrylonitrile), other peaks were maintained due to the cellulose backbone was used for the grafting reaction [67].

A blue-colored spectrum is representing the poly(amidoxime) ligand (Figure 1c). A widen peak is displayed at $3285 \mathrm{~cm}^{-1}$, which is designated the existence of $\mathrm{N}-\mathrm{H}$ stretching, while O-H bending mode was observed at $1425 \mathrm{~cm}^{-1}$. Important information regarding the previously seen typical peak representing the cellulose-graft-poly(acrylonitrile) at $2239 \mathrm{~cm}^{-1}$ was departed by the oximation resection. The additional two new bands at $1681 \mathrm{~cm}^{-1}$ and $1425 \mathrm{~cm}^{-1}$ were formed instead of $2239 \mathrm{~cm}^{-1}$, which representing the $\mathrm{C}=\mathrm{N}$ stretching and $\mathrm{N}-\mathrm{H}$ bending respectively. The evidence have proven the expected transformation of the cellulose-graft-poly(acrylonitrile) into poly(amidoxime) ligand was achieved $[57,67]$.

Figure $1 \mathrm{~d}$, which is the purple-colored spectrum, presents the poly(amidoxime)copper complex. The widen peak at $3285 \mathrm{~cm}^{-1}$ was found to affected after the formation of metal-ligand complex by mean of contribution of electron pair from the nitrogen to the copper ions. Furthermore, another important peak of poly(amidoxime) at $1681 \mathrm{~cm}^{-1}(\mathrm{C}=\mathrm{N}$ stretch) was found to shifted to $1648 \mathrm{~cm}^{-1}$ with small residue of $1681^{-1}$ (seen at $1679 \mathrm{~cm}^{-1}$ ). Therefore, the confirmation of metal-ligand complex formation by the coordination bonding is evident [49].

\subsection{Heavy Metals Adsorption by Poly(amidoxime) Ligand Effect of $\mathrm{pH}$}

A poly(amidoxime) ligand, derived from waste fibers cellulose (pandanus fiber and durian rinds), was used to metals adsorption by batch technique. We have selected four different $\mathrm{pH}$ ranging from 3-6 by buffer solution $\left(0.1 \mathrm{M} \mathrm{CH}_{3} \mathrm{COONa}\right.$ solution adapted $\mathrm{pH}$ by $\mathrm{CH}_{3} \mathrm{COOH}$ ) and four different metal ions was chosen as such copper, cobalt, chromium and nickel. The effect of $\mathrm{pH}$ versus sorption capacities are presented at Figure 2. A 
significant effect of $\mathrm{pH}$ on the adsorption capacities for all metal ions was found by the poly(amidoxime) ligand. It can be noticed that sorption capacities $\left(\mathrm{q}_{\mathrm{e}}\right)$ were elevated from $\mathrm{pH} 3$ to 6 , indicating that $\mathrm{pH} 6$ to be the most optimum condition to get the higher binding property (Figure 2). The $\mathrm{Cu}^{2+}$ displayed highest binding property which was $298.4 \mathrm{mg} \mathrm{g}^{-1}$ $\left(\mathrm{pH}\right.$ ) indicating highest affinity compared to the other metals $\left(\mathrm{Co}^{2+}, \mathrm{Cr}^{3+}\right.$, and $\left.\mathrm{Ni}^{2+}\right)$.

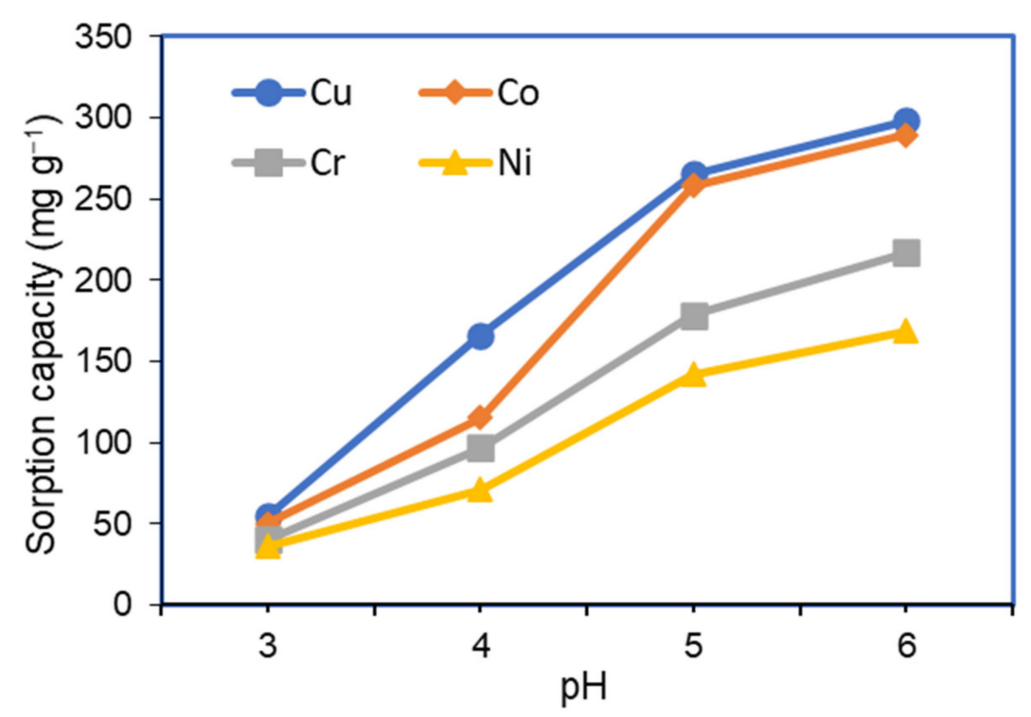

Figure 2. The effect of $\mathrm{pH}$ on the sorption behavior of heavy metals by poly(amidoxime) ligand.

The sorption values of $\mathrm{Co}^{2+}, \mathrm{Cr}^{3+}$ and $\mathrm{Ni}^{2+}$ at $\mathrm{pH} 6$ were $289.6,217.0$, and $168.7 \mathrm{mg} \mathrm{g}^{-1}$ respectively. A significant increment of heavy metal adsorption capacity can be observed from $\mathrm{pH} 3$ to $\mathrm{pH} 6$, showing that the metal ions removal by poly(amidoxime) was $\mathrm{pH}$ dependent in the order of $\mathrm{Cu}^{2+}>\mathrm{Co}^{2+}>\mathrm{Cr}^{3+}>\mathrm{Ni}^{2+}$. The existence of bidentate chelating groups rendering coordination bond between metal ions and nitrogen atom of the ligand resulted five-membered ring complexes [57,67].

The adsorption uptake action by the adsorbent contributing the functional groups$\left(\mathrm{C}\left(\mathrm{NH}_{2}\right)=\mathrm{N}-\mathrm{OH}\right)$ as the significant amphoteric features [68]. The adsorption capacity $\left(\mathrm{q}_{\mathrm{e}}\right)$ was increased up to $\mathrm{pH}$ 6. This was happened due to at low $\mathrm{pH}$ condition, the basic amino group $\left(-\mathrm{NH}_{2}\right)$ tend to be hindered from binding with the positively-charged heavy metal cations as protonation occurs at low $\mathrm{pH}$ as a result of higher concentration of $\mathrm{H}^{+}$, resulting in the formation of positively charged $-\mathrm{NH}_{3}{ }^{+}$functional group. In addition, under low $\mathrm{pH}$ conditions, the ionization of acidic hydroxyl group $(-\mathrm{OH})$ is unlikely to occur. These events resulted in reduced adsorption strength of heavy metal ions as under low $\mathrm{pH}$ conditions, there were relatively high in acidic $\mathrm{H}^{+}$cation concentrations, which competed with positively charged heavy metal cations when adsorption occurs. Therefore, adsorption uptake of heavy metal cations encountered competition with $\mathrm{H}^{+}$ions and had lower affinity towards polymeric ligand at low $\mathrm{pH}$ conditions. On the contrary, at higher acidic $\mathrm{pH}$ conditions ( $\mathrm{pH} 5-6$ ), the concentration of $\mathrm{H}^{+}$ions were relatively low. As a result, the protonation of the oxygen in the basic carbonyl group $\left(-\mathrm{NH}_{2}\right)$ was less likely to occur. Therefore, the chelating performance of basic amino group with heavy metal ions was rising. Moreover, the ionization of acidic hydroxyl group $(-\mathrm{OH})$ increased and formed negative charge oxygen ions, which favored the electrostatic interaction between the amino groups and the heavy metal cations, causing a higher adsorption strength of polymeric ligand towards metal ions, and thus ultimately resulted in the formation of metal-ligand complexes [60].

\subsection{Adsorption Kinetic Studies}

For kinetic sorption study, the contact time is needed by the poly(amidoxime) ligand for complex formation with metal ions (Figure 3). The equilibrium sorption for each interim 
period ( $5 \mathrm{~min}, 15 \mathrm{~min}, 30 \mathrm{~min}, 60 \mathrm{~min}, 120 \mathrm{~min}$ ) was determined by batch method and ICPOES was used for metal ions estimation. For kinetic study, adsorption by poly(amidoxime) ligand on selected heavy metal ions, several kinetic models were applied at $\mathrm{pH} 6$ due to the determined optimum $\mathrm{pH}$ condition for the coordination system [57]. Therefore, $\mathrm{pH} 6$ was used for each time interval when studying adsorption kinetics.

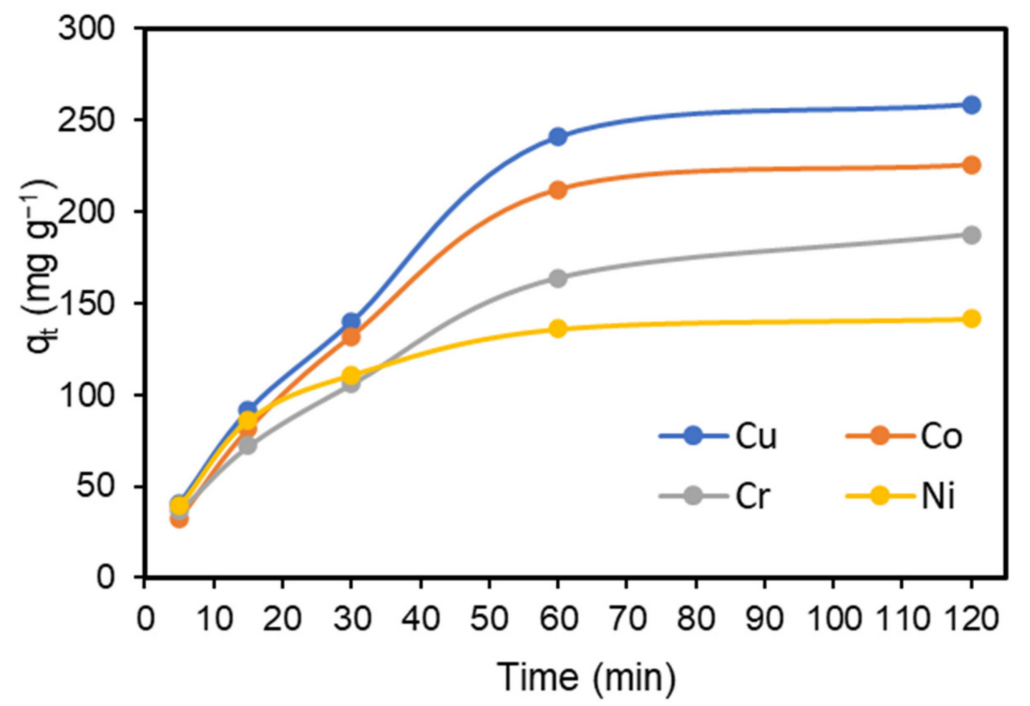

Figure 3. The effect of different contact time on the adsorption capacity of selected heavy metal ions by poly(amidoxime) ligand.

Figure 3 displays the relationship between the different sorption contact time interval and the sorption capacity of poly(amidoxime) with regards some metal ions. The adsorption kinetic study curves displayed the similar tendency by the poly(amidoxime) ligand against the time, that is, all of them showed increasing adsorption capacity as the time interim rises from $5 \mathrm{~min}$ to $120 \mathrm{~min}$ (Figure 3). The uptake of $\mathrm{Cu}^{2+}$ ions by poly(amidoxime) ligand has the highest adsorption capacity at $120 \mathrm{~min}$ time $\left(258.5 \mathrm{mg} \mathrm{g}^{-1}\right)$, while other heavy metals such as $\mathrm{Co}^{2+}, \mathrm{Cr}^{3+}$, and $\mathrm{Ni}^{2+}$ also shown considerably good adsorption capacity, $\mathrm{Co}^{2+}, \mathrm{Cr}^{3+}$, and $\mathrm{Ni}^{2+}$ sorption were $225.4,187.7$, and $141.5 \mathrm{mg} \mathrm{g}^{-1}$, respectively.

During the performance of adsorption kinetic studies via batch adsorption, all of them were performed under constant agitation. Agitation was required during the reaction as it increased the probability of even and effective collision between the molecules of heavy metal ions and the adsorbent. As a result, it increased the sorption rate. The adsorption mechanism involved the development of valance forces and exchanging of electrons between the heavy metals involved and synthesized poly(amidoxime).

According to the graph obtained in Figure 3, the heavy metals uptake by poly(amid oxime) ligand showed relatively higher rate at the early or beginning of the time intervals. For early time intervals of sorption, there were significant numbers of the amphoteric groups (the acidic $-\mathrm{NOH}$ group and basic $-\mathrm{NH}_{2}$ group) of poly(amidoxime) ligand present to be bind the heavy metal ions via complexation. Many active adsorption sites were available and more prone to heavy metal ions to be bound. Then, as we observed in the graph in Figure 3, the reaction rate of sorption slowly reduced as the interim period elevated up to $120 \mathrm{~min}$ and it ultimately reached to a plateau, designated the rate of sorption after interim period of $120 \mathrm{~min}$ was fixed [57,67]. All the adsorption of heavy metal ions is achieved equilibrium at $120 \mathrm{~min}$. This indicated that the adsorption rate after the time interval of $120 \mathrm{~min}$, finally gained to a plateau, which is the equilibrium sorption values. 


\subsubsection{Pseudo-First Order Rate}

Hereinafter expressions (3) was implemented to get the parameters of pseudo-first order rate of sorption:

$$
\log \left(\mathrm{q}_{\mathrm{e}}-\mathrm{q}_{\mathrm{t}}\right)=\log \mathrm{q}_{\mathrm{e}}-\left(\frac{\mathrm{K}_{\mathrm{ads}}}{2.303}\right) \mathrm{t}
$$

From the Equation (3), where $\mathrm{q}_{\mathrm{e}}$ and $\mathrm{q}_{\mathrm{t}}$ are the amounts of adsorbed ions $\left(\mathrm{mg} \mathrm{g}^{-1}\right)$ at equilibrium and $\mathrm{t}$ is the time in $\mathrm{min}$. While, $\mathrm{K}_{\mathrm{ads}}$ is the pseudo-first order rate constant $\left(\min ^{-1}\right)$. The $\mathrm{q}_{\mathrm{e}}$ and $\mathrm{K}_{\mathrm{ads}}$ were determined from the graph by finding the intercept and the slope of plot of $\log \left(q_{e}-q_{t}\right)$ as a function of time (Figure 4) and corresponding values were shown in Table 1. Table 1 displayed the results enumerated for the sorption capacity of all metal ions and it shows the pseudo-first order rate of sorption model and its kinetic parameters of metal ions.

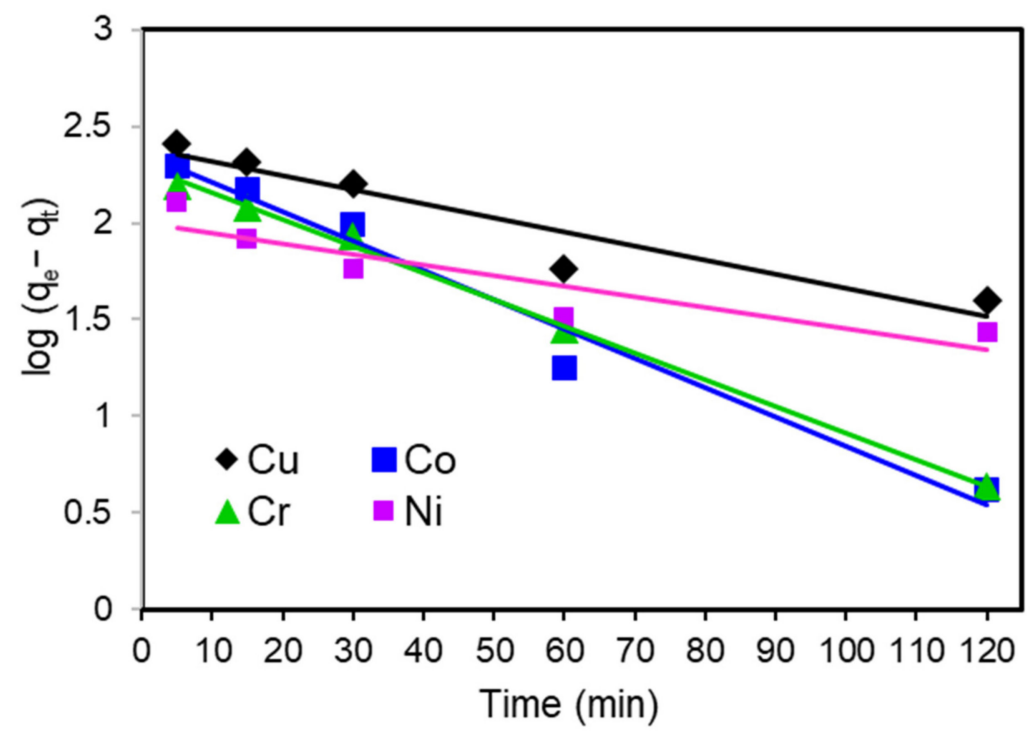

Figure 4. Pseudo-first order kinetic plots of heavy metal ions by poly(amidoxime) ligand; experimental conditions.

Table 1. Pseudo-first order rate of sorption of heavy metal ions by poly(amidoxime) ligand.

\begin{tabular}{|c|c|c|c|c|c|}
\hline \multirow{2}{*}{ Adsorbate } & \multicolumn{3}{|c|}{ Pseudo-First Order } & \multirow{2}{*}{$\begin{array}{c}\text { Experimental } \\
\mathrm{q}_{\mathrm{e}}\left(\mathrm{mg} \mathrm{g}^{-1}\right)\end{array}$} & \multirow{2}{*}{$\begin{array}{c}\text { Differences } \\
\left(\mathrm{mg} \mathrm{g}^{-1}\right)\end{array}$} \\
\hline & $q_{t}\left(m g ~ g^{-1}\right)$ & $\mathrm{K}_{\mathrm{ads}}(\mathrm{g} / \mathrm{mg} \min )$ & $\mathbf{R}^{2}$ & & \\
\hline $\mathrm{Cu}$ & 248.1 & 0.01681 & 0.9029 & 298.4 & 50.3 \\
\hline Co & 229.7 & 0.03478 & 0.9716 & 289.6 & 59.9 \\
\hline $\mathrm{Cr}$ & 195.3 & 0.03178 & 0.9972 & 217.0 & 21.7 \\
\hline $\mathrm{Ni}$ & 99.7 & 0.01267 & 0.8151 & 168.7 & 69.0 \\
\hline
\end{tabular}

Based on the calculated results obtained (Table 1$), R^{2}$ values of $C o$ and $C r$ were within acceptable range, which were 0.9716 , and 0.9972 respectively. However, $R^{2}$ values of $\mathrm{Cu}$ and $\mathrm{Ni}$ were out of the allowable scope, being 0.9029 , and 0.8151 respectively. The $\mathrm{R}^{2}$ values were relatively insignificant except $\mathrm{Cr}$. A significant deviation was observed between the experimental capacity $\left(\mathrm{q}_{\mathrm{e}}\right)$ and the enumerated sorption capacity, $\mathrm{q}_{\mathrm{t}}$ of the pseudo-first order as shown in Table 1. Therefore, the results implied that the adsorbent shows less fitting to the pseudo-first order rate model. 


\subsubsection{Pseudo-Second Order Rate}

The kinetic parameters of pseudo-second order rate equation is given by Equation (4):

$$
\frac{\mathrm{t}}{\mathrm{q}_{\mathrm{t}}}=\frac{1}{\mathrm{k}_{2} \mathrm{q}_{\mathrm{e}}^{2}}+\frac{\mathrm{t}}{\mathrm{q}_{\mathrm{e}}}
$$

where $\mathrm{k}_{2}$ is stand for pseudo-second order rate constant ( $\mathrm{g} \mathrm{mg}^{-1} \mathrm{~min}$ ), $\mathrm{q}_{\mathrm{t}}$ is the quantity of metals sorption $\left(\mathrm{mg} \mathrm{g}^{-1}\right)$ to corresponding time and $\mathrm{q}_{\mathrm{e}}$ is the quantity of the metals sorption $\left(\mathrm{mg} \mathrm{g}^{-1}\right)$ at equilibrium.

Table 2 showed the data of $\mathrm{k}_{2}$ and $\mathrm{q}_{\mathrm{e}}$ which was determined from the plot of $\mathrm{t} / \mathrm{q}_{\mathrm{t}}$ against time (Figure 5). The calculated parameters obtained in Table 2, the $\mathrm{R}^{2}$ values of $\mathrm{Cu}$, $\mathrm{Co}, \mathrm{Cr}$, and Ni were in acceptable ranges $\left(\mathrm{R}^{2}>0.99\right)$, which were $0.9769,0.9784,0.9906$, and 0.9981 respectively. All the correlation coefficient values, $\mathrm{R}^{2}$ were relatively large and very consistent as compared to that of the results shown in Pseudo-first order kinetic study of poly(amidoxime). In addition, as the experimental values $\left(q_{e}\right)$ of the heavy metal ions were compared with that of their respective calculated $q_{t}$ values, it can be observed overall, only small variation for the sorption capacity was observed of the pseudo-second order rate (Table 2) as compared to that in pseudo-first order study. Therefore, results implied that the pseudo-second order rate was a better fitting compared to the pseudo-first order according to the experimental values obtained as shown in Table 2 . The second order rate of kinetic was more predominant than pseudo-first order kinetic. This implied that the sorption mechanism obeyed chemisorption by chemically rate controlling $[63,64]$.

Table 2. Shows the pseudo-second order rate for sorption of metal ions by poly(amidoxime) ligand.

\begin{tabular}{|c|c|c|c|c|c|}
\hline \multirow{2}{*}{ Adsorbate } & \multicolumn{3}{|c|}{ Pseudo-Second Order } & \multirow{2}{*}{$\begin{array}{c}\text { Experimental } \\
\mathrm{qe}_{\mathrm{e}}\left(\mathrm{mg} \mathrm{g}^{-1}\right)\end{array}$} & \multirow{2}{*}{$\begin{array}{c}\text { Differences } \\
\left(\mathrm{mg} \mathrm{g}^{-1}\right)\end{array}$} \\
\hline & $q_{t}\left(m g g^{-1}\right)$ & $\mathrm{k}_{2}(\mathrm{~g} / \mathrm{mg} \mathrm{min}) \times 10^{-4}$ & $\mathbf{R}^{2}$ & & \\
\hline $\mathrm{Cu}$ & 357.1 & 0.6946 & 0.9769 & 298.4 & 48.7 \\
\hline Co & 312.5 & 0.8000 & 0.9784 & 289.6 & 22.9 \\
\hline $\mathrm{Cr}$ & 238.1 & 1.3183 & 0.9906 & 217.0 & 21.1 \\
\hline $\mathrm{Ni}$ & 158.7 & 4.8420 & 0.9981 & 168.7 & 10.0 \\
\hline
\end{tabular}

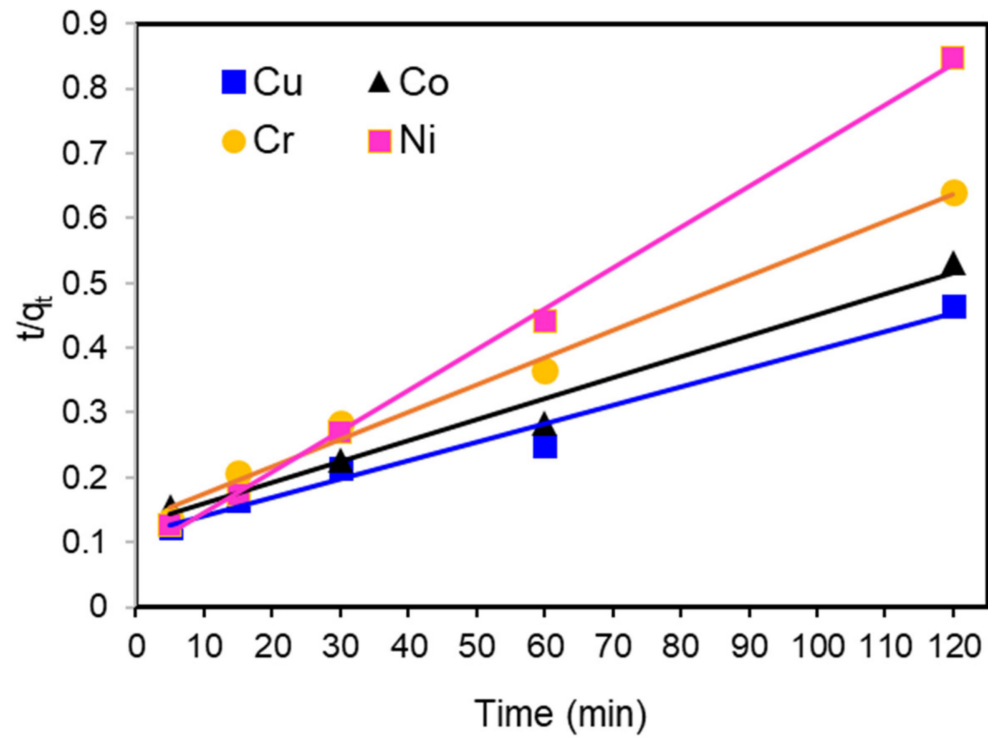

Figure 5. Pseudo-second order kinetic plots by poly(amidoxime) ligand.

\subsection{Adsorption Isothermal Studies}

Adsorption of $\mathrm{Cu}^{2+}, \mathrm{Co}^{2+}, \mathrm{Cr}^{3+}$, and $\mathrm{Ni}^{2+}$ by poly(amidoxime) ligand were performed as usual via batch adsorption process by using $100 \mathrm{mg}$ of poly(amidoxime) ligand, $\mathrm{pH}$ 
of the solutions were set at $\mathrm{pH} 6$, and agitated for $2 \mathrm{~h}$ with constant speed. The concentration of metal ions was increased from $10 \mathrm{ppm}$ to $2400 \mathrm{ppm}$. The adsorption capacity of poly(amidoxime) ligand against the four heavy metal ions at various metal solution concentrations $(10,300,600,1200$ and 2400 ppm) were display at Figure 6. While, the results obtained in Figure 6 show that the sorption capacity of poly(amidoxime) ligand towards metal ions was higher with the increase in the initial metal concentrations. It was also seen that sorption capacity slowly increased up to a plateau, then the equilibrium was attained as seen in the graph (Figure 6).

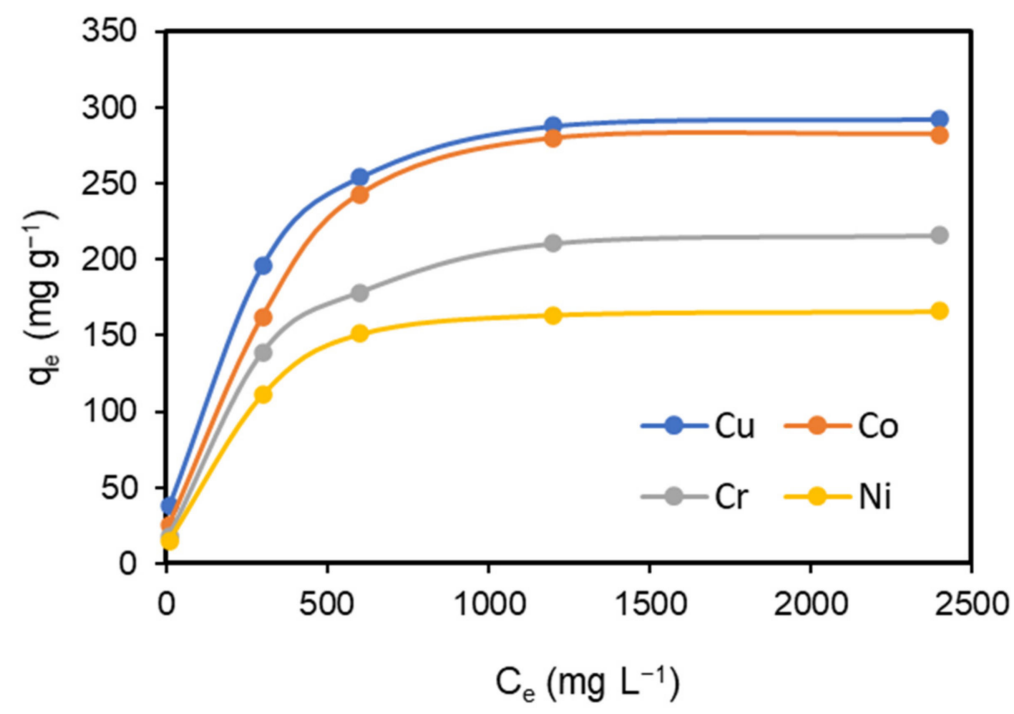

Figure 6. The effect of different initial heavy metal ion concentrations on adsorption capacity by poly(amidoxime) ligand.

Therefore, the most common isothermal models, including Langmuir isotherm model and Freundlich isotherm pattern were chosen to study the isothermal behaviors. Therefore, common linear forms of Langmuir and Freundlich isotherm pattern were selected due to the mathematical simplicity of linear form model itself $[61,62]$.

\subsubsection{Linear Langmuir Adsorption Isotherm}

The following Equation (5) can used for a linear form of Langmuir adsorption isotherm model:

$$
\frac{\mathrm{C}_{\mathrm{e}}}{\mathrm{q}_{\mathrm{e}}}=\frac{1}{\mathrm{q}_{\max } \mathrm{K}_{\mathrm{L}}}+\frac{\mathrm{C}_{\mathrm{e}}}{\mathrm{q}_{\max }}
$$

As referred to the equation above, $\mathrm{q}_{\mathrm{e}}\left(\mathrm{mg} \mathrm{g}^{-1}\right)$ is the equilibrium sorption capacity by the sorbent, $C_{e}\left(\mathrm{mg} \mathrm{L}^{-1}\right)$ stand for equilibrium concentration of metal ions, $\mathrm{q}_{\max }\left(\mathrm{mg} \mathrm{g}^{-1}\right)$ and $\mathrm{K}_{\mathrm{L}}\left(\mathrm{L} \mathrm{mg}^{-1}\right)$ represented the maximum capacity of the adsorbent and Langmuir adsorption constant, respectively. Equation (5) was correlated with the general assumptions stated by Langmuir's adsorption isotherm model [62].

By applying the Equation (5), the $\mathrm{q}_{\mathrm{e}}$ values are enumerated from the slopes of the linear lines of $\frac{C_{e}}{q_{e}}$ versus $C_{e}$, which is linear plots of Langmuir adsorption isotherm as shown in Figure 7. Accordingly, the $\mathrm{K}_{\mathrm{L}}$ values are also enumerated from the intercepts of the linear lines of $\frac{C_{e}}{q_{e}}$ versus $C_{e}$ (Figure 7). Based on the data obtained in Table 3, the parameter of correlation coefficient $\left(R^{2}\right)$ shows all are noteworthy values, in which $R^{2}>0.99$. Enumerated adsorption capacity strength of $\mathrm{Cu}^{2+}>\mathrm{Co}^{2+}>\mathrm{Cr}^{3+}>\mathrm{Ni}^{2+}$ were 303.0, 294.1, 227.3 , and $172.4 \mathrm{mg} \mathrm{g}^{-1}$, respectively, which was highly matched with the order recorded in the previous $\mathrm{pH}$ and kinetic studies. Furthermore, there were only small differences between the enumerated Langmuir $\mathrm{q}_{\mathrm{e}}$ values and the experimental obtained $\mathrm{q}_{\text {expt }}$ values. 
Therefore, since all of them were having $\mathrm{R}^{2}>0.99$, it can be concluded that a single or monolayer adsorption was occurred on the surface of the poly(amidoxime) ligand.

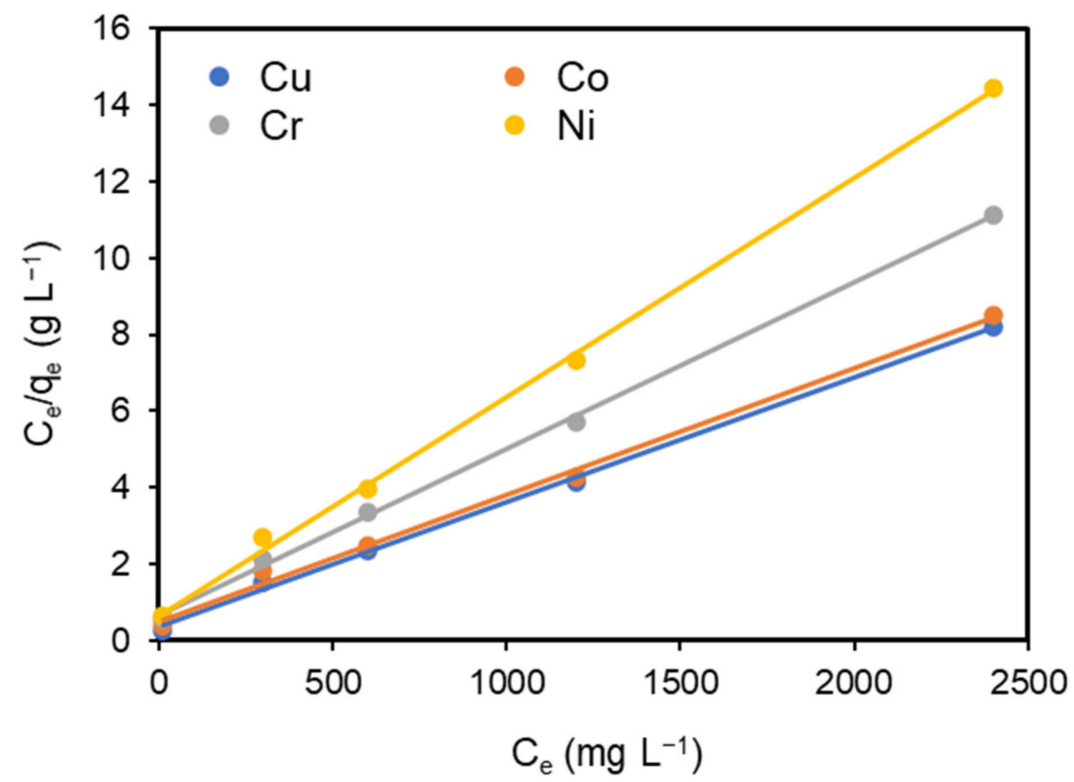

Figure 7. Linear plots of Langmuir adsorption isotherm of metal ions by poly(amidoxime) ligand.

Table 3. Linear Langmuir adsorption isotherm parameters of poly(amidoxime) ligand.

\begin{tabular}{|c|c|c|c|c|}
\hline \multirow{2}{*}{ Adsorbent } & \multicolumn{3}{|c|}{ Langmuir } & \multirow{2}{*}{$\begin{array}{c}\text { Differences with } \\
\text { qexpt }_{\left(\mathrm{mg} \mathrm{g}^{-1}\right)}\end{array}$} \\
\hline & $\mathrm{q}_{\mathrm{e}}\left(\mathrm{mg} \mathrm{g}^{-1}\right)$ & $\mathrm{K}_{\mathrm{L}}\left(\mathrm{L} \mathrm{mg}^{-1}\right)$ & $\mathbf{R}^{2}$ & \\
\hline $\mathrm{Cu}^{2+}$ & 303.0 & 0.009544 & 0.998 & 4.6 \\
\hline $\mathrm{Co}^{2+}$ & 294.1 & 0.006788 & 0.995 & 4.5 \\
\hline $\mathrm{Cr}^{3+}$ & 227.3 & 0.006683 & 0.997 & 10.3 \\
\hline $\mathrm{Ni}^{2+}$ & 172.4 & 0.01111 & 0.998 & 3.7 \\
\hline
\end{tabular}

\subsubsection{Linear Freundlich Adsorption Isotherm}

The following Equation (6) can used for a linear form of Freundlich isotherm model:

$$
\log \mathrm{q}_{\mathrm{e}}=\log \mathrm{K}_{\mathrm{F}}+\frac{\log \mathrm{C}_{e}}{\mathrm{n}} .
$$

Based on the Equation (6), the parameter $\mathrm{q}_{\mathrm{e}}$ and $\mathrm{C}_{e}$ are representing the same units as expressed in Equation (5). However, $\mathrm{K}_{\mathrm{F}}$ stand for Freundlich's constant, and $1 / \mathrm{n}$ is the heterogeneity factor which is associated with the binding property [61].

According to the Equation (6), the $\mathrm{n}$ values are enumerated from the slope of the linear plots of Freundlich adsorption isotherm, on the other hand, all constants $\mathrm{K}_{\mathrm{F}}$ are also enumerated from the intercepts of the linear plots of $\log q_{e}$ versus $\log C_{e}$ (Figure 8). Based on the parameters (Table 4), the correlation coefficients were relatively insignificant, whereby $\mathrm{R}^{2}<0.95$. In addition, by comparing the $\mathrm{R}^{2}$ values with the Langmuir adsorption isotherm, the $R^{2}$ values were more significant, indicating that Langmuir isotherm was more dominant than Freundlich isotherm. Therefore, it was unlikely to have multilayer adsorption on the heterogenous surface of the poly(amidoxime) ligand. 


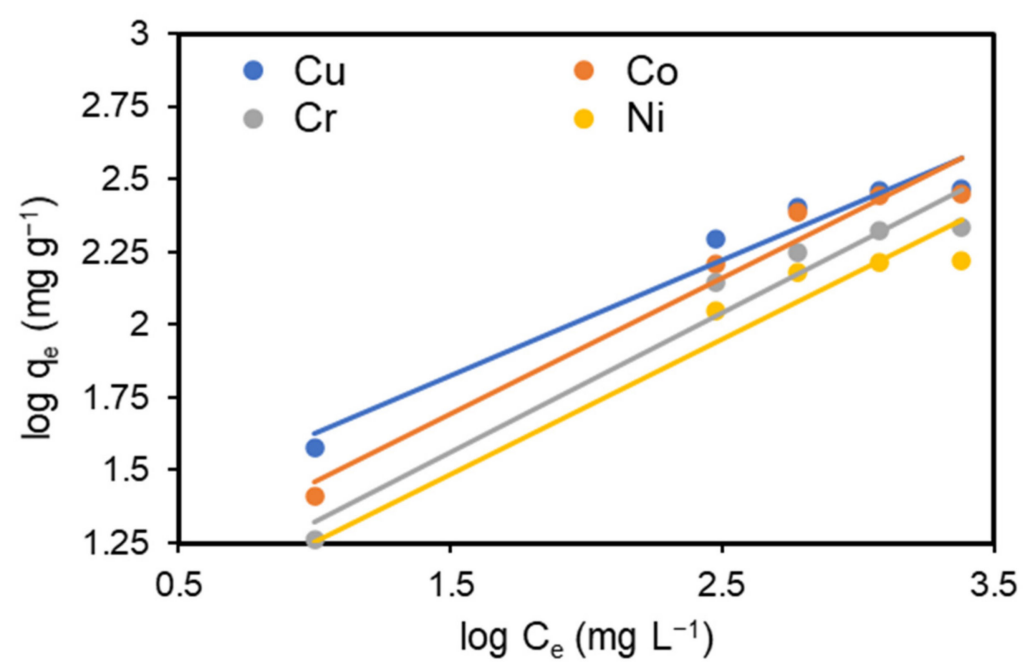

Figure 8. Linear plots of Freundlich adsorption isotherm of metal ions by poly(amidoxime) ligand.

Table 4. Linear Freundlich adsorption isotherm parameters of poly(amidoxime) ligand.

\begin{tabular}{cccc}
\hline \multirow{2}{*}{ Adsorbent } & \multicolumn{3}{c}{ Freundlich } \\
\cline { 2 - 4 } & $\mathbf{n}$ & $\mathbf{K}_{\mathbf{F}} \mathbf{( \mathbf { L ~ m g }} \mathbf{~} \mathbf{1}^{\mathbf{1}}$ & $\mathbf{R}^{\mathbf{2}}$ \\
\hline $\mathrm{Cu}^{2+}$ & 2.8458 & 23.3024 & 0.956 \\
\hline $\mathrm{Co}^{2+}$ & 2.2936 & 12.3851 & 0.962 \\
\hline $\mathrm{Cr}^{3+}$ & 2.9931 & 18.9365 & 0.965 \\
\hline $\mathrm{Ni}^{2+}$ & 3.3091 & 18.7499 & 0.943 \\
\hline
\end{tabular}

According to the calculated results in Table 5, it can be notice that the Langmuir model has smaller HYBRID and MPSD values (detail information about HYBRID and MPSD stated in supporting information). Smaller HYBRID and MPSD values indicated smaller error in the estimation of $\mathrm{q}_{\mathrm{e}}$ values in the isotherm model. As a result, Langmuir model had more accurate and less error of estimating $\mathrm{q}_{\mathrm{e}}$ values, suggesting that Langmuir isotherm model was the best fit and provides a better model of explaining the isothermal behavior of heavy metal ions adsorption by poly(amidoxime) ligand [57].

Table 5. Isotherm parameters and error functions for adsorption onto poly(amidoxime) ligand.

\begin{tabular}{cccccc}
\hline \multirow{2}{*}{ Adsorbent } & \multicolumn{5}{c}{ Langmuir } \\
\cline { 2 - 6 } & $\left.\mathbf{q}_{\mathbf{e}} \mathbf{( m g ~ g}^{-\mathbf{1}}\right)$ & $\left.\mathbf{K}_{\mathbf{L}} \mathbf{( L ~ m g}^{-\mathbf{1}}\right)$ & $\mathbf{R}^{\mathbf{2}}$ & HYBRID & MPSD \\
\hline $\mathrm{Cu}$ & 303.0 & 0.009544 & 0.998 & 0.1688 & 19.6227 \\
\hline $\mathrm{Co}$ & 294.1 & 0.006788 & 0.995 & 0.1974 & 20.3125 \\
\hline $\mathrm{Cr}$ & 227.3 & 0.006683 & 0.997 & 0.1017 & 10.5916 \\
\hline $\mathrm{Ni}$ & 172.4 & 0.01111 & 0.998 & 0.1162 & 13.4317 \\
\hline
\end{tabular}

\subsection{Reusability Study of Poly(amidoxime) Ligand}

The function and usefulness of poly(amidoxime) ligand was quite similar to our previous work [57]. Therefore, its reusability in real-life applications has been an emphasized, in order to prove its cost-effectiveness. The reusability study involved elution and regeneration of the poly(amidoxime) ligand. Similarly, the complexation of heavy metal ions by poly(amidoxime) ligand is unlikely to occur at very low $\mathrm{pH}$, as it is very susceptible to the desorption process as the adsorbed metal cations can be desorbed from the poly(amidoxime) adsorbent at very low $\mathrm{pH}$, such as $\mathrm{pH} 1$ [69]. Therefore, the adsorbed 
metal cations were extracted from the adsorbent by using $2 \mathrm{M}$ of $\mathrm{HCl}$ solution [67]. In this study, cobalt-poly(amidoxime) complex was desorbed using $\mathrm{HCl}$ solution. After sufficiently washing with distil water, the adsorbent was reused again and about 6 cycles of adsorption-desorption processes conducted by the same cobalt-poly(amidoxime) complex.

According to the adsorption capacity results obtained in earlier sections, the adsorption capacity of $\mathrm{Co}^{2+}$ ions by poly(amidoxime) ligand at optimum conditions was $289.6 \mathrm{mg} \mathrm{g}^{-1}$. Therefore, as referred to this result, the \% sorption and extraction were enumerated for each cycle. Based on the results displayed in Figure 9, the efficiency rate realized only about $7 \%$ loss over 6 cycles, indicating that the poly(amidoxime) ligand had a noticeable recyclability feature, and can be used in the extraction of toxic metal ions present in the wastewaters.

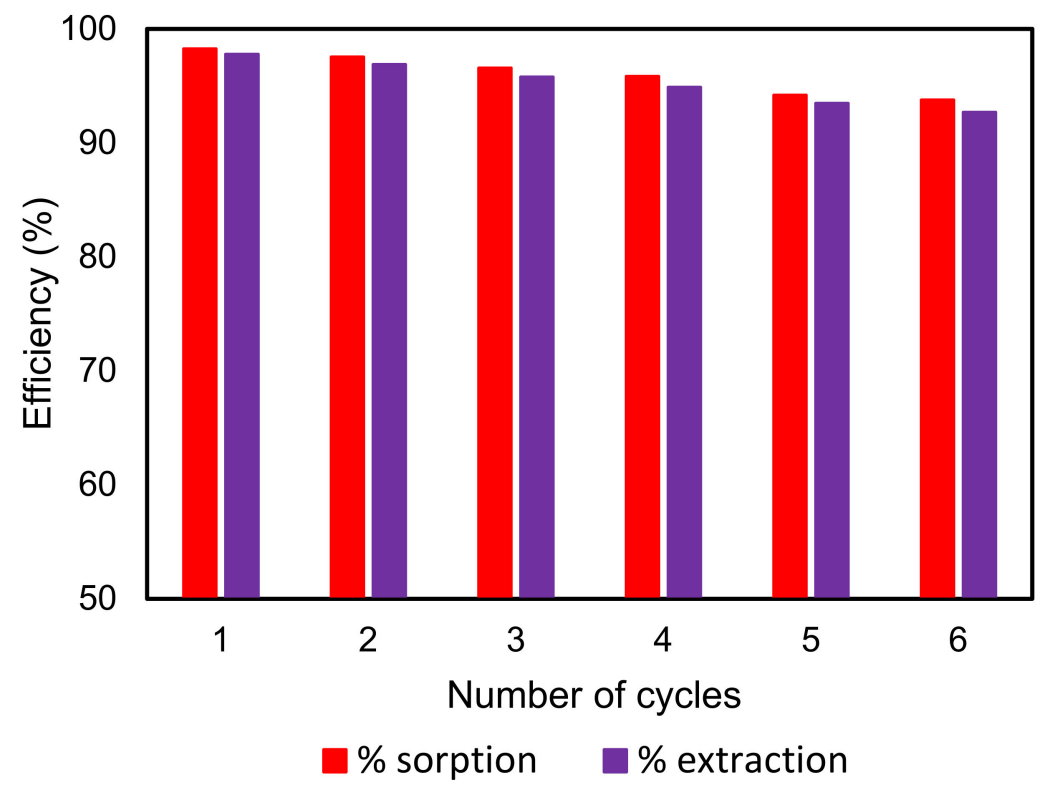

Figure 9. Reusability study of poly(amidoxime) in 6 cycles of adsorption-desorption of $\mathrm{Co}^{2+}$ ions.

\subsection{Practical Application of Poly(Amidoxime) Ligand}

By utilizing poly(amidoxime) ligand in the elimination of toxic metal ions in the actual application. Table 6 showed the analytical results by ICP-OES (metal ions concentrations before treatment and after ligand treatment) in electroplating wastewater specimen (IWS 1 and IWS 2) obtained from an electroplating industry (PCB etching) Porcel, Singapore.

Table 6 and Figure 10 displayed that the limit of metal ions in the wastewater specimen was reduced after treatment with the polymeric chelating poly(amidoxime) ligand under optimum conditions. The $\mathrm{Cu}^{2+}$ and $\mathrm{Fe}^{3+}$ removal capacity was about $95 \%$, which is higher than the other heavy metal ions. While, the elimination of other metal ions $\left(\mathrm{Pb}^{2+}, \mathrm{Zn}^{2+}, \mathrm{Cr}^{3+}\right.$, $\mathrm{Mn}^{2+}$, and $\mathrm{Ni}^{2+}$ ) also showed somewhat better removing capacity, overall, approximately 70 to $90 \%$ can be removed after treatment with poly(amidoxime) ligand.

Several additional metal ions were also recognized in the wastewater after analyzing with ICP-OES. Alkali metals $\left(\mathrm{K}^{+}, \mathrm{Rb}^{+}\right.$and $\left.\mathrm{Na}^{+}\right)$and alkaline earth metals $\left(\mathrm{Ba}^{2+}, \mathrm{Ca}^{2+}\right.$ and $\left.\mathrm{Mg}^{2+}\right)$ including others ions $\left(\mathrm{Ag}^{+}, \mathrm{V}^{4+}\right.$ and $\left.\mathrm{Al}^{3+}\right)$, which was originally detected in the wastewater and their concentration was also reduced after treatment with poly(amidoxime) ligand. However, the removal was relatively low, compared to the transition metal ions. Therefore, this polymeric adsorbent can be promising for removing toxic heavy metal ions in industrial wastewater. 
Table 6. Compositions of metal ions in the industrial wastewater samples (IWS 1 and IWS 2) before and after treatment by poly(amidoxime) ligand.

\begin{tabular}{|c|c|c|c|c|c|c|}
\hline \multirow[b]{2}{*}{ Metal Ions } & \multicolumn{3}{|c|}{ IWS 1} & \multicolumn{3}{|c|}{ IWS 2} \\
\hline & $\begin{array}{c}\text { Before Treatment } \\
\text { ppm }\end{array}$ & $\begin{array}{c}\text { After Treatment } \\
\text { ppm }\end{array}$ & $\begin{array}{c}\% \\
\text { Removal }\end{array}$ & $\begin{array}{c}\text { Before Treatment } \\
\text { ppm }\end{array}$ & $\begin{array}{c}\text { After Treatment } \\
\text { ppm }\end{array}$ & $\begin{array}{c}\% \\
\text { Removal }\end{array}$ \\
\hline $\mathrm{Fe}^{3+}$ & 32.0095 & 1.7666 & 94.48 & 1.4637 & 0.07325 & 95.00 \\
\hline $\mathrm{Cu}^{2+}$ & 23.0493 & 2.3495 & 89.81 & 85.7627 & 2.6798 & 96.88 \\
\hline $\mathrm{Pb}^{2+}$ & 0.0207 & 0.003644 & 82.42 & 0.1331 & 0.03863 & 70.98 \\
\hline $\mathrm{Zn}^{2+}$ & 0.0421 & 0.01089 & 74.15 & 0.1037 & 0.009508 & 90.83 \\
\hline $\mathrm{Cr}^{3+}$ & 0.0268 & 0.005666 & 78.90 & 0.0857 & 0.007291 & 91.49 \\
\hline $\mathrm{Mn}^{2+}$ & 0.1296 & 0.02947 & 77.27 & 0.0055 & 0.001171 & 78.56 \\
\hline $\mathrm{Ni}^{2+}$ & 0.01828 & 0.007549 & 58.71 & 0.4421 & 0.1380 & 68.78 \\
\hline $\mathrm{Ba}^{2+}$ & 0.0013 & 0.0006328 & 51.06 & - & - & - \\
\hline $\mathrm{Ca}^{2+}$ & 0.5517 & 0.3081 & 44.15 & 0.8918 & 0.4259 & 52.24 \\
\hline $\mathrm{Rb}^{+}$ & 0.0305 & 0.01863 & 38.98 & 0.0109 & 0.007929 & 26.96 \\
\hline $\mathrm{K}^{+}$ & 0.0783 & 0.05301 & 32.28 & 0.2791 & 0.2130 & 23.67 \\
\hline $\mathrm{Na}^{+}$ & 15.23 & 13.0675 & 14.18 & 9.7411 & 8.0518 & 17.34 \\
\hline $\mathrm{V}^{4+}$ & 0.0000648 & 0.0000544 & 16.01 & - & - & - \\
\hline $\mathrm{Al}^{3+}$ & 0.0505 & 0.04518 & 10.54 & 0.0063 & 0.006138 & 3.13 \\
\hline $\mathrm{Ag}^{+}$ & - & - & - & 0.0322 & 0.01467 & 54.36 \\
\hline $\mathrm{Mg}^{2+}$ & - & - & - & 0.0879 & 0.05250 & 40.24 \\
\hline
\end{tabular}

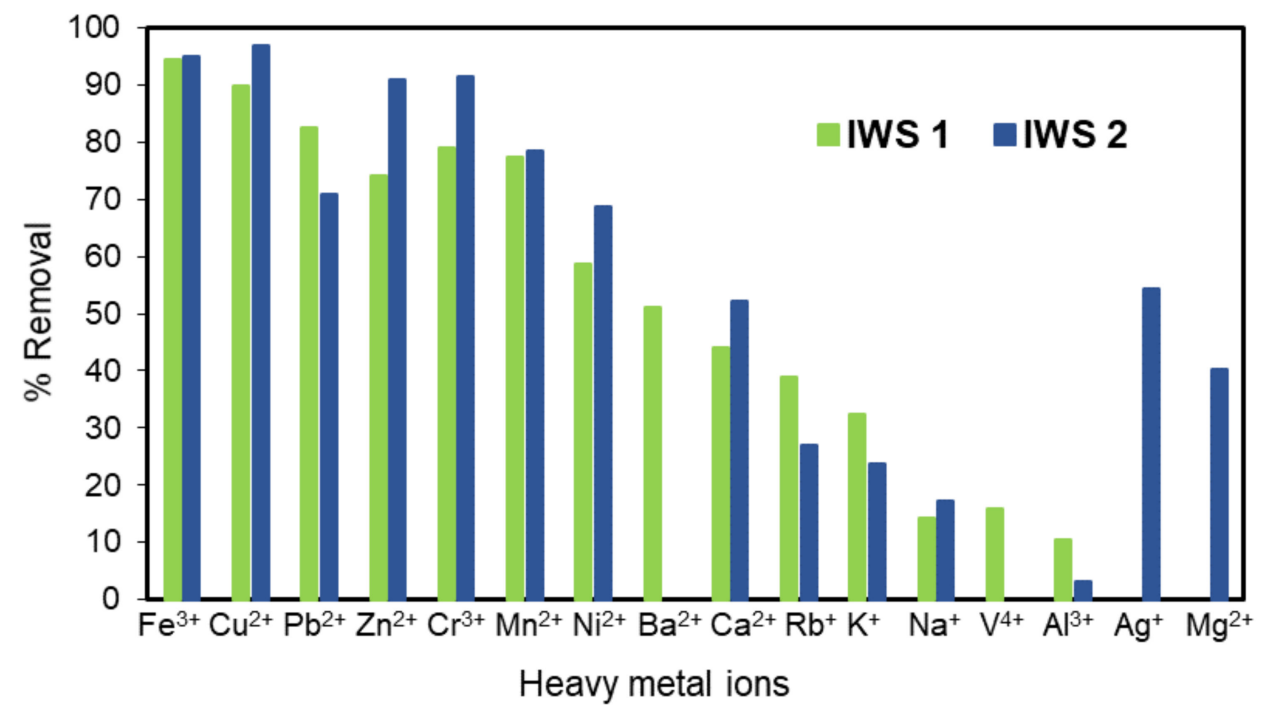

Figure 10. Removal of metal ions in industrial wastewater (IWS1 and IWS12) by poly(amidoxime).

Liu et al. [21] recently reported on the elimination of heavy metals from electroplating wastewater effluent by upcycling of sludge. They used two kinds of $\mathrm{Co}$ and $\mathrm{Cr}$ bearing sludge, S1 comprising Fe and Co and S2 comprising Fe and Cr (S2). A recyclable adsorbent, SP1, was prepared from S1 using a simplistic hydrothermal path with the inclusion of hydrated sodium sulfide. On the other hand, another recyclable adsorbent, SP2 was prepared from S2 using same hydrothermal method. Both SP1 and SP2 were used in the treatment process, a trace amount of Co was released in wastewater from SP1, whereas SP2 does not releases any $\mathrm{Cr}$ in wastewater. Exactly $300 \mathrm{mg}$ of SP2 used for removal study showed that metals removing from electroplating wastewater were 99.7, 99.4, 37.9 and $53.3 \%$ of $\mathrm{Zn}, \mathrm{Cu}, \mathrm{Ni}$, and $\mathrm{Co}$, respectively (Table 7). Liu et al. [21] concluded that 
SP2 exhibited higher removal efficiency compared with SP1 due to the formation of a well-crystallized erdite nanorod in SP2.

Ajmal et al. [25] utilized the Kyanite for the elimination of four metal ions from electroplating wastewater. The metal ions were recovered with $0.05 \mathrm{M} \mathrm{HCl}$ from adoption onto Kyanite adsorbent. The recovery of metal ions was depending on the capacity of adsorption of metal ions by Kyanite. Thus, copper, zinc, nickel and chromium recovery were $38.4,60,30$, and $35 \%$, respectively (Table 7). A wetland was used for the treatment of electroplating waste and three types of wetland setups were utilized with column sorption process [11]. The percentage elimination of all metals was found to be more than $90 \%$, and the wetland (Cell 3) gave different removal percentage as shown in Table 7. You et al. [70] also used a wetland set-up along with a plant to remove the heavy metals from electroplating wastewater containing $\mathrm{Cr}, \mathrm{Cu}$ and $\mathrm{Ni}$. The results showed that metal concentration was significantly reduced of $\mathrm{Cr}, \mathrm{Cu}$ and $\mathrm{Ni}$ in wastewater by $84.4 \%, 97.1 \%$, and $94.3 \%$, respectively (Table 7). Other adsorbents like rise husk, coconut coir, corncobbased activated carbon (CAC), powdered activated carbon (PAC), powdered activated carbon modified with sodium diethyldithiocarbamate (PAC-SDDC), were less effective. However, they are workable in removing heavy metals from wastewater, as shown in Table 7.

Bankole et al. [15] recently reported on two new nano-adsorbents generated by catalytic chemical vapour deposition (CCVD) process, one is the purified carbon nanotubes (P-CNTs) and the other is the polyhydroxylbutyrate carbon nanotubes (PHB-CNTs). The PHB-CNTs is more efficient compared to P-CNTs, in order to remove heavy metals from wastewater. They studied the elimination efficiency of heavy metals, such as arsenic, lead, iron, zinc, nickel, cadmium, chromium, lead and copper using batch adsorption technique. The results of heavy metal eliminations with different capacities are shown in Table 7. Recently, we prepared a poly(amidoxime) ligand from a pure cellulose extracted from palm fiber. Pure cellulose was used to grafting reaction with acrylonitrile monomer by free radical reaction and further converted into poly(amidoxime) by oximation reaction [57]. The adsorbent $(500 \mathrm{~g}$ ) was used in metal ion elimination from electroplating wastewater. The removal of metal ions was observed to be very good, ranging in the range of $90-98 \%$ (Table 7). Recently, we also prepared pure cellulose, extracted from jute fiber and modified with acrylonitrile monomer, using a free radical grafting reaction and subsequently transformed into poly (amidoxime) ligand [67]. The polymer adsorbent $(500 \mathrm{mg})$ was used to remove heavy metals from the industrial electroplating wastewater. The removal efficiency was found to be very good, ranging between $90-98 \%$ (Table 7). The present study showed a similar removal efficiency compared to our previous work. However, we used waste fibers from pandanus fruit and durian rind, as well as a small quantity of adsorbent (300 mg) used for heavy metal elimination from electroplating wastewater (Table 7).

In principle, a ligand possessing a pair of electrons of the ions or molecules, which is surrounding to the central metal atom resulting a complex/coordination compound. Given the interest in toxic metal removal from wastewaters, a polymeric ligand, namely the hydroxamic acid ligand, was derived from the modified waste fiber cellulose. Thus, a lone pair of electrons exists in the nitrogen and oxygen atoms of the amidoxime groups, which loses a lone pair of electrons, and is co-ordinated with metal ions [49]. The cellulose moderation into the metal-binding ligands exhibiting notable differences is observed in the sorption magnitude. Various mechanisms of metal binding are known to us including ion exchange, complexation, co-ordination/chelation, electrostatic interactions etc. [61]. The binding properties of modified cellulose-based poly(hydroxamic acid) ligand is greatly affected by the types of metals and other conditions of sorption process $[66,67]$. 
Table 7. Percentage removal of different adsorbent on various types of electroplating wastewater.

\begin{tabular}{|c|c|c|c|c|}
\hline Adsorbent & $\begin{array}{l}\text { Dosage Used } \\
\text { (mg) }\end{array}$ & Adsorbate & Maximum Percentage Removal (\%) & References \\
\hline SP1 & 300 & Electroplating wastewater & $\mathrm{Zn}(99), \mathrm{Cu}(99), \mathrm{Ni}(44)^{\mathrm{a}}, \mathrm{Co}(20)^{\mathrm{b}}$ & [21] \\
\hline SP2 & 300 & Electroplating wastewater & $\mathrm{Zn}(99) \mathrm{Cu}(99), \mathrm{Ni}(50)^{\mathrm{a}}, \mathrm{Co}(60)^{\mathrm{b}}$ & [21] \\
\hline Rice husk & 367 & RIEW & $\mathrm{Cr}$ (74), Cd (79), Cu (38), Ni (99) & [71] \\
\hline Coconut coir & 367 & RIEW & $\mathrm{Cr}$ (93), Cd (40), Cu (39), Ni (99) & [71] \\
\hline CAC & 1000 & RIEW & $\mathrm{Cr}(95)$ & [72] \\
\hline PAC & 3000 & SIEW & Ni(89), Zn (90), Cr (89) & [73] \\
\hline PAC-SDDC & 3000 & SIEW & Ni(82), Zn (85), Cr (97) & [73] \\
\hline Kyanite & 500 & Electroplating wastewater & $\mathrm{Cu}(38), \mathrm{Zn}(60), \mathrm{Ni}(30), \mathrm{Cr}(35)$ & [25] \\
\hline Wetland & $\mathrm{C}$ & Electroplating wastewater & $\mathrm{Ni}(99), \mathrm{Cu}(98), \mathrm{Zn}(92), \mathrm{Co}(98)$ & [11] \\
\hline Wetland + plant & $\mathrm{W}$ & Electroplating wastewater & $\mathrm{Cr}(84), \mathrm{Cu}(97), \mathrm{Ni}(94)$ & [70] \\
\hline P-CNTs & 20 & RIEW & $\begin{array}{l}\mathrm{Fe}(92), \mathrm{Ni}(90), \mathrm{Cd}(99), \mathrm{Pb}(99), \mathrm{Cu} \\
(93), \mathrm{Zn}(89), \mathrm{Cr}(99)\end{array}$ & [15] \\
\hline PHB-CNTs & 20 & RIEW & $\begin{array}{l}\mathrm{Fe}(93), \mathrm{Ni}(90), \mathrm{Cd}(99), \mathrm{Pb}(99), \mathrm{Cu} \\
(93), \mathrm{Zn}(86), \mathrm{Cr}(99)\end{array}$ & [15] \\
\hline PA-Palm & 500 & Electroplating wastewater (1) & $\begin{array}{l}\mathrm{Cu}(98), \mathrm{Fe}(98), \mathrm{Zn}(76), \mathrm{Pb}(97), \mathrm{Co}(95), \mathrm{Cr} \\
(97), \mathrm{Ni}(97)\end{array}$ & [57] \\
\hline PA-Palm & 500 & Electroplating wastewater (2) & $\begin{array}{l}\mathrm{Cu}(98), \mathrm{Fe}(98), \mathrm{Zn}(70), \mathrm{Pb}(96), \mathrm{Co}(95), \mathrm{Cr} \\
(97), \mathrm{Ni}(85)\end{array}$ & [57] \\
\hline PA-Jute & 500 & Electroplating wastewater (S1) & $\mathrm{Fe}(96), \mathrm{Cu}(98), \mathrm{Pb}(90), \mathrm{Zn}(80), \mathrm{Cr}(93), \mathrm{Ni}(86)$ & [67] \\
\hline PA-Jute & 500 & Electroplating wastewater (S2) & $\mathrm{Fe}(98), \mathrm{Cu}(98), \mathrm{Pb}(87), \mathrm{Zn}(92), \mathrm{Cr}(95), \mathrm{Ni}(91)$ & [67] \\
\hline PA-waste & 300 & PCB electroplating wastewater (IWS 1) & $\mathrm{Fe}$ (94), $\mathrm{Cu}(90), \mathrm{Pb}(82), \mathrm{Zn}(74), \mathrm{Cr}(79), \mathrm{Ni}(59)$ & This study \\
\hline PA-waste & 300 & PCB electroplating wastewater (IWS 2) & $\mathrm{Fe}$ (95), $\mathrm{Cu}$ (97), $\mathrm{Pb}(70), \mathrm{Zn}(91), \mathrm{Cr}(91), \mathrm{Ni}(69)$ & This study \\
\hline
\end{tabular}

Abbreviation: Short rod-like erdite particles (SP1), Long nanorod erdite particles (SP2), Raw Industrial Electroplating Wastewater (RIEW), Simulated industrial electroplating wastewater (SIEW), Corncob based activated carbon (CAC), Powdered activated carbon (PAC), Powdered activated carbon modified with sodium diethyldithiocarbamate (PAC-SDDC), Purified carbon nanotubes (P-CNTs), Polyhydroxylbutyrate functionalized carbon nanotubes (PHB-CNTs), ${ }^{a}=800 \mathrm{mg}$ dose, ${ }^{b}=800 \mathrm{mg}$ dose, $\mathrm{C}=$ adsorbent filled in column, and $\mathrm{W}=$ wetland set-up, Poly(amidoxime) from palm fiber (PA-Palam), Poly(amidoxime) from jute fiber (PA-Jute) and Poly(amidoxime) from waste fiber (PA-waste).

\section{Conclusions}

In this study, a poly(amidoxime) ligand was prepared from waste fruit fiber. The heavy metal removal studies such as effect of $\mathrm{pH}$, sorption contact time (kinetic), isothermal study, ligand reusability and practical applications were evaluated. It was found that the adsorption of copper, cobalt, chromium, and nickel by poly(amidoxime) was $\mathrm{pH}$ dependent. According to the results obtained from the kinetic study, the adsorption process obeyed the pseudo-second order rate of sorption, in which the coefficient was relatively significant $\left(R^{2}>0.98\right)$ compared to the of pseudo-first order rate of sorption. The isothermal studies, performed in this study, also showed that the adsorption isothermal behavior of poly(amidoxime) ligand was best fitted with Langmuir adsorption isotherm pattern $\left(R^{2}>0.99\right)$, recommending the poly(amidoxime) ligand exhibit homogenous surface and monolayer adsorption is feasible. The reusability behavior of polymer adsorbent showed that it can be useful up to six cycles with minimum loss (7\%) of efficiency. For the practical application of poly(amidoxime) ligand to remove heavy metals from the electroplating wastewaters, one containing a high concentration of copper and iron with trace levels of other heavy metals and another containing high concentration of copper only with trace level of others heavy metals. A significant removal behavior found that up to $98 \%$ of toxic metal ions can be removed from electroplating wastewater by the poly(amidoxime) ligand. 
Supplementary Materials: The following are available online at https:/ /www.mdpi.com/article/ 10.3390/w13091260/s1, Figure S1: The image shows poly(amidoxime) ligand with metal-complex as the poly(amidoxime) - Cu (left), poly(amidoxime) - Co (second left), poly(amidoxime)—Cr (3rd from left) and poly(amidoxime)—Ni (utmost right), Scheme S1: Poly(acrylonitrile)-grafted cellulose, poly(amidoxime) ligand and poly(amidoxime)—-metal complex (CL indicated an anhydroglucose unit).

Author Contributions: Methodology, Z.J.W.; formal analysis, S.E.A.; resources, B.M.; visualization, K.B.; data curation, S.S.; writing-review and editing, M.L.R.; project administration, M.S.S.; All authors have read and agreed to the published version of the manuscript.

Funding: This research was funded by Research management Centre, Universiti Malaysia Sabah.

Institutional Review Board Statement: Not applicable.

Informed Consent Statement: Not applicable.

Data Availability Statement: The data presented in this study are available on request from the first author.

Acknowledgments: This research was supported by the Skim UMSGreat, funding no. GUG0350$1 / 2019$.

Conflicts of Interest: The author declared no conflict of interest.

\section{References}

1. Ajibade, F.O.; Adelodun, B.; Lasisi, K.H.; Fadare, O.O.; Ajibade, T.F.; Nwogwu, N.A.; Sulaymon, I.D.; Ugya, A.Y.; Wang, H.C.; Wang, A. Environmental Pollution and their Socioeconomic Impacts. In Microbe Mediated Remediation of Environmental Contaminants; Elsevier BV: Amsterdam, The Netherlands, 2021; pp. 321-354.

2. Jaishankar, M.; Tseten, T.; Anbalagan, N.; Mathew, B.B.; Beeregowda, K.N. Toxicity, Mechanism and Health Effects of Some Heavy Metals. Interdiscip. Toxicol. 2014, 7, 60-72. [CrossRef] [PubMed]

3. Hajeeth, T.; Vijayalakshmi, K.; Gomathi, T.; Sudha, P. Removal of Cu(II) and Ni(II) using Cellulose Extracted from Sisal Fiber and Cellulose-G-Acrylic Acid Copolymer. Int. J. Biol. Macromol. 2013, 62, 59-65. [CrossRef] [PubMed]

4. Gunatilake, S.K. Methods of Removing Toxic Metals for Industrial Wastewater. J. Multi. Engineer. Sci. Stud. 2015, 1, 12-18.

5. Arshad, H.; Iram, J.; Nadeem, A.K. Characterization and Treatment of Electroplating Industry Wastewater using Fenton's Reagent. J. Chem. Pharma. Res. 2014, 6, 622-627.

6. Mehdipour, S.; Vatanpour, V.; Kariminia, H.-R. Influence of Ion Interaction on Lead Removal by a Polyamide Nanofiltration Membrane. Desalination 2015, 362, 84-92. [CrossRef]

7. Martín-Lara, M.; Blázquez, G.; Trujillo, M.; Pérez, A.; Calero, M. New Treatment of Real Electroplating Wastewater Containing Heavy Metal Ions by Adsorption onto Olive Stone. J. Clean. Prod. 2014, 81, 120-129. [CrossRef]

8. Chowdhury, M.; Mostafa, M.; Biswas, T.K.; Saha, A.K. Treatment of Leather Industrial Effluents by Filtration and Coagulation Processes. Water Resour. Ind. 2013, 3, 11-22. [CrossRef]

9. Sochacki, A.; Faure, O.; Guy, B.; Surmacz-Górska, J. Role of Natural and Constructed Wetlands in Nutrient Cycling and Retention on the Landscape: Polishing of Real Electroplating Wastewater in Microcosm Fill-and-Drain Constructed Wetlands; Vymazal, J., Ed.; Springer International Publishing: New York, NY, USA, 2015; pp. 203-227.

10. Kanjan, U. Solution for Wastewater Problem Related to Electroplating Industry: An Overview. J. Ind. Pollut. Control 2006, 22, 59-66.

11. Sudarsan, J.S.; Deeptha, V.T.; Deepak, M.; Mukesh, G.; Kumar, K.R.; Das, A. Study on Treatment of Electroplating Wastewater using Constructed Wetland. Nat. Environ. Pollut. Technol. 2015, 14, 95-100.

12. Rahman, M.L.; Sarkar, S.M.; Yusoff, M.M. Efficient removal of heavy metals from electroplating wastewater using polymer ligands. Front. Environ. Sci. Eng. 2016, 10, 352-362.

13. Bai, D.-K.; Ying, Q.-H.; Wang, N.; Lin, J.-H. Copper Removal from Electroplating Wastewater by Coprecipitation of Copper-Based Supramolecular Materials: Preparation and Application Study. J. Chem. 2016, 2016, 1-7. [CrossRef]

14. Maleki, A.; Hayati, B.; Najafi, F.; Gharibi, F.; Joo, S.W. Heavy Metal Adsorption from Industrial Wastewater by PAMAM/TiO2 Nanohybrid: Preparation, Characterization and Adsorption Studies. J. Mol. Liq. 2016, 224, 95-104. [CrossRef]

15. Bankole, M.T.; Abdulkareem, A.S.; Mohammed, I.A.; Ochigbo, S.S.; Tijani, J.O.; Abubakre, O.K.; Roos, W.D. Selected Heavy Metals Removal From Electroplating Wastewater by Purified and Polyhydroxylbutyrate Functionalized Carbon Nanotubes Adsorbents. Sci. Rep. 2019, 9, 1-19. [CrossRef] [PubMed]

16. Mizushima, I.; Tang, P.T.; Hansen, H.N.; Somers, M.A. Development of a New Electroplating Process for Ni-W Alloy Deposits. Electrochim. Acta 2005, 51, 888-896. [CrossRef]

17. Wang, G.; Sui, J.; Wang, C.; Cai, G. Treatment of Electroplating Synthetical Wastewater by Combined Process of Oxidation and Reduction, Coagulation and Sedimentation. China Water Wastewater 2007, 23, 57. 
18. Zhang, Z.; Li, L.; Zhu, H.; Wang, F.; Hua, J. Removing Chromium from Electroplating Wastewater by Chemical Precipitation. Environ. Sci. Technol. 2008, 31, 96-97.

19. Lin, Y.-M.; Yen, S.-C. Effects of Additives and Chelating Agents on Electroless Copper Plating. Appl. Surf. Sci. 2001, 178, 116-126. [CrossRef]

20. Celary, P.; Sobik-Szołtysek, J. Vitrification as an Alternative to Landfilling of Tannery Sewage Sludge. Waste Manag. 2014, 34, 2520-2527. [CrossRef]

21. Liu, Y.; Khan, A.; Wang, Z.; Chen, Y.; Zhu, S.; Sun, T.; Liang, D.; Yu, H. Upcycling of Electroplating Sludge to Prepare Erdite-Bearing Nanorods for the Adsorption of Heavy Metals from Electroplating Wastewater Effluent. Water 2020, 12, 1027. [CrossRef]

22. Andrus, M.E. A Review of Metal Precipitation Chemicals for Metal-Finishing Applications. Met. Finish. 2000, 98, 20-23. [CrossRef]

23. Guo, X.; Liu, J.; Tian, Q. Elemental Behavior of Multi-Component Metal Powders from Waste Printed Circuit Board during Low-Temperature Alkaline Smelting. Chin. J. Nonferrous Met. 2013, 23, 1757-1763.

24. Sze, Y.P.; Xue, L.Z.; Lee, M.Y. Treatment of Alloy-Electroplating Wastewater by an Automated Solvent Extraction Technique. Environ. Technol. 2001, 22, 979-990. [CrossRef]

25. Ajmal, M.; Rao, R.A.K.; Ahmad, R.; Ahmad, J.; Rao, L.A.K. Removal and Recovery of Heavy Metals from Electroplating Wastewater by using Kynaite as an Adsorbent. J. Hazard. Mater. 2001, 87, 127-137. [CrossRef]

26. Zhonghe, M.; Zhumei, W.; Ming, J. Treatment of Low Concentration Complex Nickel Chromium(Cr6+) Copper mixed Electroplating Wastewater. Mod. Chem. Res. 2018, 11, 26-27.

27. Sun, H.M.; Song, L.; Guo, J.; Zhang, L. Fate of $\mathrm{NaClO}$ and Membrane Foulants during in-Situ Cleaning of Membrane Bioreactors: Combined Effect on Thermodynamic Properties of Sludge. Biochem. Eng. J. 2019, 147, 146-152.

28. Sun, M.; Yan, L.; Zhang, L.; Song, L.; Guo, J.; Zhang, H. New Insights into the Rapid Formation of Initial Membrane Fouling after in-Situ Cleaning in a Membrane Bioreactor. Process. Biochem. 2019, 78, 108-113. [CrossRef]

29. Xu, T.; Lei, X.; Sun, B.; Yu, G.; Zeng, Y. Highly Efficient and Energy-Conserved Flocculation of Copper in Wastewater by Pulse-Alternating Current. Environ. Sci. Pollut. Res. 2017, 24, 20577-20586. [CrossRef] [PubMed]

30. Wang, Z.; Ye, G.; Yang, Y. Low-Concentration Electroplating Wastewater Treatment by Heavy Metal Chelator. J. Zhejiang Univ. 2010, 37, 665-669.

31. Shih, Y.-J.; Lin, C.-P.; Huang, Y.-H. Application of Fered-Fenton and Chemical Precipitation Process for the Treatment of Electroless Nickel Plating Wastewater. Sep. Purif. Technol. 2013, 104, 100-105. [CrossRef]

32. Tembhekar, P.; Padoley, K.; Mudliar, S. Kinetics of Wet Air Oxidation Pretreatment and Biodegradability Enhancement of a Complex Industrial Wastewater. J. Environ. Chem. Eng. 2015, 3, 339-348. [CrossRef]

33. Yong, L. Progress of Electroplating Wastewater Treatment with Micro-Electrolysis Method. Guangdong Chem. Ind. 2008, 35, 56.

34. Li, Y.; Zeng, X.; Liu, Y.; Yan, S.; Hu, Z.; Ni, Y. Study on the Treatment of Copper-Electroplating Wastewater by Chemical Trapping and Flocculation. Sep. Purif. Technol. 2003, 31, 91-95. [CrossRef]

35. Repo, E.; Warchoł, J.K.; Bhatnagar, A.; Mudhoo, A.; Sillanpää, M. Aminopolycarboxylic Acid Functionalized Adsorbents for Heavy Metals Removal from Water. Water Res. 2013, 47, 4812-4832. [CrossRef] [PubMed]

36. Fadel, D.; El-Bahy, S.; Abdelaziz, Y. Heavy Metals Removal using Iminodiacetate Chelating Resin by Batch and Column Techniques. Desalin. Water Treat. 2016, 57, 25718-25728. [CrossRef]

37. Benouali, D.; Kherici, S.; Belabbassi, M.; Belkandouci, M.; Bennemra, A. Preliminary Study of Zinc Removal from Cyanide-free Alkaline Electroplating Effluent by Precipitation using Oxalis Plants. Orient. J. Chem. 2014, 30, 515-519. [CrossRef]

38. Š́ciban, M.; Radeti 'c, B.; Kevrešan, Ž.; Klašnja, M. Adsorption of Heavy Metals from Electroplating Wastewater by Wood Sawdust. Bioresour. Technol. 2007, 98, 402-409. [CrossRef]

39. Mahmoodi, N.M.; Sadeghi, U.; Maleki, A.; Hayati, B.; Najafi, F. Synthesis of Cationic Polymeric Adsorbent and Dye Removal Isotherm, Kinetic and Thermodynamic. J. Ind. Eng. Chem. 2014, 20, 2745-2753. [CrossRef]

40. Mnasri-Ghnimi, S.; Frini-Srasra, N. Removal of Toxic Metals from Aqueous Solutions by Adsorption using Single and Mixed Pillared Clays. Appl. Clay Sci. 2019, 179, 105151. [CrossRef]

41. Zhang, Y.; Duan, X. Chemical Precipitation of Toxic Metals from Wastewater by using the Synthetical Magnesium Hydroxy Carbonate. Water Sci. Technol. 2020, 81, 1130-1136. [CrossRef]

42. Tang, X.; Zheng, H.; Teng, H.; Sun, Y.; Guo, J.; Xie, W. Chemical Coagulation Process for the Removal of Toxic Metals from Water: A review. Desalin. Water Treat. 2016, 57, 1733-1748. [CrossRef]

43. Bashkim, S.T.; Salih, T.G. Reverse osmosis Removal of Toxic Metals from Wastewater Effluents using Biowaste Materials Pretreatment. Pol. J. Environ. Stud. 2019, 28, 337-341.

44. Khulbe, K.C.; Matsuura, T. Removal of Heavy Metals and Pollutants by Membrane Adsorption Techniques. Appl. Water Sci. 2018, 8, 19. [CrossRef]

45. Gupta, V.; Carrott, P.; Singh, R.; Chaudhary, M.; Kushwaha, S. Cellulose: A review as Natural, Modified and Activated Carbon Adsorbent. Bioresour. Technol. 2016, 216, 1066-1076. [CrossRef]

46. Zhu, F.; Zheng, Y.-M.; Zhang, B.-G.; Dai, Y.-R. A Critical Review on the Electrospun Nanofibrous Membranes for the Adsorption of Heavy Metals in Water Treatment. J. Hazard. Mater. 2021, 401, 123608. [CrossRef] [PubMed]

47. Abegunde, S.M.; Idowu, K.S.; Adejuwon, O.M.; Adeyemi-Adejolu, T. A Review on the Influence of Chemical Modification on the Performance of Adsorbents. Resour. Environ. Sustain. 2020, 1, 100001. [CrossRef] 
48. Sun, Z.; Wang, M.; Fan, J.; Zhou, Y.; Zhang, L. Regeneration Performance of Activated Carbon for Desulfurization. Appl. Sci. 2020, 10, 6107. [CrossRef]

49. Rahman, L.; Sarkar, S.M.; Yusoff, M.M.; Abdullah, M.H. Efficient Removal of Transition Metal Ions using Poly(Amidoxime) Ligand from Polymer Grafted Kenaf Cellulose. RSC Adv. 2015, 6, 745-757. [CrossRef]

50. Chmielewská, E. Natural Zeolite: Alternative Adsorbent in Purification or Post-Treatment of Waters. Modif. Clay Zeol.Nanocompos. Mater. Environ. Pharma. Appl. 2018, 87-112. [CrossRef]

51. Rahman, L.; Sarjadi, M.S.; Arshad, S.E.; Musta, B.; Heffeman, M.A.; O'Reilly, E.J.; Sarkar, S.M. Synthesis of Silica-Supported Hydroxamic Ligand for Removal of Metals Ions from Water. J. Nanosci. Nanotechnol. 2021, 21, 1570-1577. [CrossRef] [PubMed]

52. Wang, M.; Qu, R.; Sun, C.; Yin, P.; Chen, H. Dynamic Adsorption Behavior and Mechanism of Transition Metal Ions on Silica gels Functionalized with Hydroxyl- or Amino-Terminated Polyamines. Chem. Eng. J. 2013, 221, 264-274. [CrossRef]

53. Chua, S.F.; Nouri, A.; Ang, W.L.; Mahmoudi, E.; Mohammad, A.W.; Benamor, A.; Ba-Abbad, M. The Emergence of Multifunctional Adsorbents and their Role in Environmental Remediation. J. Environ. Chem. Eng. 2021, 9, 104793. [CrossRef]

54. Wadhawan, S.; Jain, A.; Nayyar, J.; Mehta, S.K. Role of Nanomaterials as Adsorbents in Heavy Metal ion Removal from Wastewater: A Review. J. Water Proc. Eng. 2020, 33, 101038. [CrossRef]

55. Kang, H.; Liu, R.; Huang, Y. Graft Modification of Cellulose: Methods, Properties and Applications. Polymer 2015, 70, A1-A16. [CrossRef]

56. Rahman, M.L.; Mandal, B.H.; Sarkar, S.M.; Yusoff, M.M.; Arshad, S.; Musta, B. Synthesis of Poly(Amidoxime) Ligand from Polymer Grafted Corn-Cob Cellulose for Transition Metals Extraction. Polym. Adv. Technol. 2016, 27, 1625-1636. [CrossRef]

57. Rahman, M.L.; Fui, C.J.; Sarjadi, M.S.; Arshad, S.E.; Musta, B.; Abdullah, M.H.; Sarkar, S.M.; O’Reilly, E.J. Poly (Amidoxime) Ligand Derived from Waste Palm Fiber for the Removal of Toxic Metals from Electroplating Wastewater. Environ. Sci. Pollut. Res. 2020, 27, 34541-34556. [CrossRef] [PubMed]

58. Rahman, M.L.; Biswas, T.K.; Sarkar, S.M.; Yusoff, M.M.; Sarjadi, M.S.; Arshad, S.E.; Musta, B. Adsorption of Rare Earth Metals from Water using a Kenaf Cellulose-Based Poly(Amidoxime) Ligand. J. Mol. Liq. 2017, 243, 616-623. [CrossRef]

59. Rahman, M.L.; Mandal, B.H.; Sarkar, S.M.; Wahab, N.A.A.; Yusoff, M.M.; Arshad, S.E.; Musta, B. Synthesis of Poly (Amidoxime) Ligand from Polymer Grafted Khaya Cellulose for Transition Metals Extraction. Fibers Polym. 2016, 17, 521-532. [CrossRef]

60. Dmitrii, S.B.; Nadezhda, A.B.; Vadim, Y.K. Coordination Chemistry and Metal-Involving Reactions of Amidoximes: Relevance to the Chemistry of Oximes and Oxime Ligands. Coord. Chem. Rev. 2016, 313, 62-93.

61. Swenson, H.; Stadie, N.P. Langmuir's Theory of Adsorption: A Centennial Review. Langmuir 2019, 35, 5409-5426. [CrossRef]

62. Appel, J. Freundlich's Adsorption Isotherm. Surf. Sci. 1973, 39, 237-244. [CrossRef]

63. Pan, Y.; Wang, F.; Wei, T.; Zhang, C.; Xiao, H. Hydrophobic Modification of Bagasse Cellulose Fibers with Cationic Latex: Adsorption Kinetics and Mechanism. Chem. Eng. J. 2016, 302, 33-43. [CrossRef]

64. Zheng, L.; Dang, Z.; Yi, X.; Zhang, H. Equilibrium and Kinetic Studies of Adsorption of Cd(II) from Aqueous Solution using Modified Corn Stalk. J. Hazard. Mater. 2010, 176, 650-656. [CrossRef]

65. Awual, R.; Yaita, T.; El-Safty, S.A.; Shiwaku, H.; Suzuki, S.; Okamoto, Y. Copper(II) Ions Capturing from Water using Ligand Modified a New Type Mesoporous Adsorbent. Chem. Eng. J. 2013, 221, 322-330. [CrossRef]

66. Larkin, P.J. IR and Raman Spectra-Structure Correlations: Characteristics Group Frequencies. In IR and Raman Spectroscopy Principles and Spectral Interpretation; Elsevier: Amsterdam, The Netherlands, 2017; pp. 73-115.

67. Rahman, L.; Fui, C.J.; Ting, T.X.; Sarjadi, M.S.; Arshad, S.E.; Musta, B. Polymer Ligands Derived from Jute Fiber for Heavy Metal Removal from Electroplating Wastewater. Polymer 2020, 12, 2521. [CrossRef] [PubMed]

68. Siew, S.Y.W.; Rahman, M.L.; Arshad, S.E.; Surugau, N.L.; Musta, B. Synthesis and Characterization of Poly (Hydroxamic Acid)-Poly (Amidoxime) Chelating Ligands from Polymer-Grafted Acacia Cellulose. J. Appl. Polym. Sci. 2012, 124, $4443-4451$.

69. Nilchi, A.; Rafiee, R.; Babalou, A.A. Adsorption Behavior of Metal Ions by Amidoxime Chelating Resins. Macromol. Symp. 2008, 274, 101-108. [CrossRef]

70. You, S.-H.; Zhang, X.-H.; Liu, J.; Zhu, Y.-N.; Gu, C. Feasibility of Constructed Wetland Planted with Leersia Hexandraswartz for Removing Cr, Cu and Ni from Electroplating Wastewater. Environ. Technol. 2013, 35, 187-194. [CrossRef] [PubMed]

71. Frency, M. Removal of Heavy Metals from Electroplating Wastewater Using Rice Husk and Coconut Coir. Master's Thesis, Missouri University of Science and Technology, Rolla, MO, USA, 2008.

72. Garg, K.K.; Rawat, P.; Prasad, B. Removal of Cr (VI) and COD from Electroplating Wastewater by Corncob Based Activated Carbon. Inter. J. Water Wastewater Treat. 2015, 1, 1-9.

73. Tae-Kyoung, K.; Kim, T.; Choe, W.S.; Kim, M.K.; Jung, Y.J.; Zoh, K.D. Removal of Heavy Metals in Electroplating Wastewater by Powdered Activated Carbon (PAC) and Sodium Diethyldithiocarbamate-Modified PAC. Environ. Eng. Res. 2018, 23, 301-308. 